Денис Иоффе

Брюссельский университет

Denis.Ioffe@ulb.be

Dennis Ioffe

Université libre de Bruxelles

Denis.Ioffe@ulb.be

\title{
К ВОПРОСУ О ПЕРФОРМАТИВНОЙ МНОГОЗНАЧНОСТИ РУССКОГО МАТА ${ }^{1}$
}

\section{DEBATING RUSSIAN OBSCENE PERFORMATIVITY AND POLYSEMY: THE CURIOUS CASE OF RUSSIAN MAT}

В статье обсуждаются разноплановые случаи противоречивой перформативной многозначности русской обсценной табуированной лексики, обычно именуемой «мат». Особое внимание уделяется радикальной карнавальной абсурдности (Бахтин) и прагматической поливалентности обсуждаемых идиоматических высказываний. В статье также уделено внимание различным ракурсам полисемии. Работа предварительно очерчивает контуры будущей теории обсценного высказывания в связи с шизоаналитической ризомой ее языкового функционирования.

Ключевые слова: теории высказывания, амфиболии, полисемия, прагматика, словесное безумие, полифония, русская обсценная идиоматика, шизоанализ.

The article focuses on discussing the vibrant multimodality cases of self-contradictory performative utterances of the Russian taboo idiomatic, usually referred to as 'mat'. Particular attention is paid to the carnivalesque Bakhtinian absurdity and pragmatic polyvalence of the discussed idiomatic expressions. Polysemy in its turn stays also in the center of the essay. The paper proposes a preliminary outline of the future theory of obscene utterances in connection with the schizoanalytical rhizome of its linguistic functioning.

Keywords: Russian obscenities, theories of utterance, polysemy, amphiboly, pragmatics, verbal madness, polyphony, Russian idiomatics, schizoanalysis.

1.

Известно, что языковая перформативность - это по преимуществу категория прагматики, а не семантики. «Перформативная многозначность» в нашем понимании - это контекстуальная, ситуативная многозначность,

1 Автор искренне благодарит Алексея Юдина, Игоря Пильщикова, Михаила Клебанова и Андрея Россомахина за ценные замечания и разнообразную помощь в работе над текстом этой статьи. 
какова, например, артикуляция значения матерной формулой в конкретной ситуации той или иной перформативной функции. В этом ракурсе можно рассмотреть связь некоторых контекстуальных значений и перформативных функций, связанных с матерными «словесными ситуациями». Существуют работы по лексической и словообразовательной полисемии, однако наши замечания должны влиться в область исследований полисемии контекстуальной, ситуативной, а также связанной с перформативной функцией экспрессивного проклятия или присяги - или подобных этому смыслов, возникающих в русской матерной идиоматике.

Как нам представляется, многозначность русского мата связана с комплексными вопросами полисемии, с рассмотрением интересных и уже плодотворно изучавшихся феноменов, когда лингвистическая многовариантность (семантики) предполагает наличие у слова как гнездово-словарной единицы языка ${ }^{2}$ двух и более фиксированно-идиоматических значений, так или иначе исторически обусловленных или частично взаимосвязанных по своему смысло-происхождению. Полисемия в языке может также связываться с феноменом комплексной системы, существующей в художественной литературе и известной как сложносочлененная «полифония». Эта проблема была впервые полномасштабно обозначена М. М. Бахтиным на примере многих (и в чем-то многозначных) «голосов» речи ${ }^{3}$ у Достоевского, в значительной степени экземплифицировавшего этот процесс в русской и мировой литературе и культуре ${ }^{4}$.

Мы рассмотрим некоторые наиболее характерные примеры русской обсценной экспрессивной лексики, связанные с комплексом проблем полисемии. Напомним кратко, о чем здесь может идти речь. Лексическая многозначность выступает как вариабильная способность того или иного слова служить для обозначения принципиально разных предметов и явлений видимой действительности ${ }^{5}$, ассоциативно перекликающихся между собой и образующих сложное семантическое диффузионное пространственное

2 Есть гнездовое слово в словаре; соответственно, имеются гнездовой толковый или словообразовательный словари. Можно считать, что язык тоже устроен не только по принципам парадигматики и синтагматики, но также и по родственно-гнездовому принципу, актуализирующему деривационные и иные взаимоотношения между однокоренными словами.

3 Концепция Бахтина заключается в том, что у Достоевского по сути уравниваются голоса персонажей с авторским, который тоже становится одним из голосов в романе. Позиция говорящего речетворца-персонажа становится де факто независимой от позиции автора. При этом формально Бахтин говорит не об уровнях и аспектах языка, но скорее об уровнях порождаемых речевых жестов и смыслов.

4 При этом, согласно Бахтину, полифония - это не только своего рода речевой креативный процесс, но и также «структурная константа» определенного типа художественной прозы.

5 Упомянем еще, что полисемия чаще касается сферы стиля (стили языка) и стратификации социолектов (крестьянская хата, на хате у кореша, пресс-хата...; закопал клад, я тебя закопаю!) - или различения между конкретным и абстрактным, метафорически названным именно потому, что не поддается эмпирическому наблюдению и прямому называнию (засеянное поле, электромагнитное поле, лексико-семантическое поле, поле новых идей, и т. д.). 
единство ${ }^{6}$. Лингвистическая полисемия представляется нам классическим диалектическим явлением присвоения и уточнения логоцентрических смыслов $^{7}$, где никогда нельзя говорить о конечности значения ${ }^{8}$ или узуса, который всегда есть совокупность ситуаций использования языкового знака, реальное функционирование которого как бы противопоставлено парадигматической дескриптивной или прескриптивной «норме». Эта совокупность ситуаций по определению открыта и бесконечна, потому разговор у нас идет лишь о перманентном становлении, усложнении и синтетическом перерождении первичного ядра ${ }^{9}$ того или иного (в греческом смысле видимого как $\lambda$ ó $о \varsigma)$ Verbum.

Речь также идет о способности всякой лексической единицы приобретать более чем одно значение, притом что все возможные значения одного слова фактически сотворяют его семантическую смысловую структуруулей ${ }^{10}$. Используя полисемию многозначности для называния нового понятия, язык приходит таким образом не к утверждению совершенно нового слова, но скорее к радикальному насыщению и расширению семантической структуры того или иного уже сущзествующего. В силу изначальной лингво-экономии средств и в силу интенции обобщения происходит видоизменение семантической структуры слов, проявления в ней новых смыслов, тесно связанных с принципом «смыслового обобщения» как универсальным семио-способом передачи многопланового значения и его интуитивных производных. Прагматика полисемии оказывается, таким образом, следствием ее непосредственной узусной практики, а дальнейшая фиксация смыслов уже механически следует за ними ${ }^{11}$.

Тема полисемии и многозначности напрямую увязывается с вопросами риторических техник амфиболии. Августин в своем знаменитом трактате «О Христианском учении» говорит (кн. 2, гл. XXIV):

6 Cм. Cuyckens 1997: 35-54; Kleiber 1999; Borowsky, Masson 1996: 63-85; Verspoor, Lowies 2003: 547-586; Jastrzembski 1981: 278-305.

7 Речь идет и о языковой концептуализации реальности, которая утверждается и усваивается вместе с усвоением всякого языка.

8 Напомним, что значение никогда не бывает окаменевшим и бесповоротно-окончательным, оно де факто постоянно изменяется во времени, но в данный момент, здесь и сейчас, в синхронном срезе системы и ее сиюминутном использовании оно бывает определенным и окончательным, потому что иначе не произойдет коммуникации.

9 Мы не будем здесь задаваться сложным вопросом о том, существует ли вообще «первичное ядро» слова. Вместе с тем почти всегда имеется мотивационная база при морфологической или семантической деривации (в синхронии) и также имеется этимон (с его «базовым» значением) в диахронии. Все это довольно произвольно принятые нами «точки отсчета», которые сами есть результаты исторического развития формы и значения, переосмысления, деривации. Язык системно ригиден в синхронии, чтобы гарантировать успешность коммуникации, и бесконечно текуч и изменчив в диахронии. Все «первичные ядра» так или иначе условны, как и «внутренняя форма слова», которой на русском материале плодотворно занимались А. А. Потебня и Г. Г. Шпет.

10 CM. Tsunoda 1994: 4670-4677; Gibbs, Matlock 2001: 213-239; Nunberg 1995: 109-132; Klepousniotou 2007: 1-24; Rodd 2002: 245-266.

11 См., в частности: Ravin, Leacock 2000; Hino, Pexman, Lupker 2006: 247-273; Klein, Murphy 2001: 259-282. 
...к слову сказать, крестообразная форма буквы X, например, у греков значит одно, а у латинян - другое не по природе, но для выражения значения по предписанию и уговору <... >. И «бета» при одном и том же звучании у греков - название буквы, а у латинян — огородной зелени; и когда я произношу двусложное Lege, то грек понимает одно, а латинянин иное. [Ho] все эти значения <...> [потому действуют], что люди согласились на них. Так же и знаки, с помощью которых устанавливается опасная связь с демонами, имеют вес в зависимости от благочестия каждого [человека]. (Августин 2001: 85)

«Амфиболия - это двусмысленность, возникающая от многозначности» (Гаспаров 2001: 30). Известно, что амфиболия призвана констатировать более или менее сознательную двусмысленность, возникающую из многозначности одного слова или сочетания слов. Сам термин происходит от греческого $\alpha \mu \varphi 1 \beta о \lambda i ́ \alpha:$ «двусмысленность - неясность выражения, возникающая в результате ряда причин стилистического порядка» (Квятковский 1966: 26). Амфиболичность, по нашему мнению, является одним из главных языковых прагматических свойств русского стёба, являющегося в свою очередь одним из частных случаев функционирования русской экспрессивной фразеологии, в том числе русского мата. Амфиболия нередка в русской поэзии. Ее причиной может явиться «структурная неясность в построении предложения, чаще всего двусмысленность, когда существительное в именительном падеже трудно отличимое от прямого дополнения в винительном падеже, т. е., проще говоря, неизвестно — “кто кого”», например: «Брега Арагвы и Куры / Узрели русские шатры» (А. С. Пушкин) или: «В Сенеке строгий стоицизм / Давно разрушил организм!» (А. Н. Майков), и т. п. (Квятковский 1966: 26).

О связи иронического и амфиболического дискурсов (текстуальной двусмысленности) написано немало (ср. Иоффе 2006: 123-124). Ирония, в силу своей суггестивной семиотичности, как бы демонстрирует болезненное несовпадение между видимым в реальности знаком и его обобщенноидеальным значением, т. е. между планом идей и миром их актуального воплощения ${ }^{12}$. Об этом ведет речь Кьеркегор в трактате о сократической иронии — «О понятии иронии с постоянным обращением к Сократу», опубликованном в 1841 году (см. Иоффе 2006: 133-134). Ирония, думается, по своей природе есть некая особая ноуменальная субстанция особого дискурсивного рода. Она служит одним из способов называть вещи условнопротивоположными именами. В узком смысле ирония - это антифразис

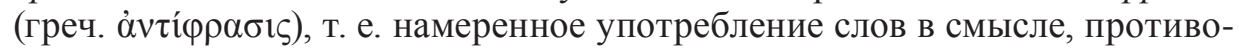
положном их общепринятому словарному значению.

12 В отличие от иронии, ее смысло-риторический кузен сарказм (образованный

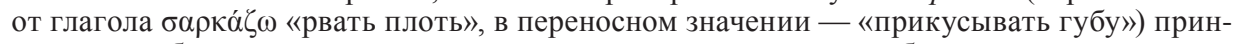
ципиально более язвителен и ядовит, радикально увеличивая собственно сам градус наступательной иронии и результирующую степень контраста планов подразумеваемого и выражаемого. Сарказму свойственно также брутальное семиотическое обнажение непосредственно «подразумеваемого», которое в меньшей степени прикрывается туманностью тропов. В этом процессе момент негодования и даже ненависти оказывается более открыт и менее двусмыслен чем в иронии per se. 


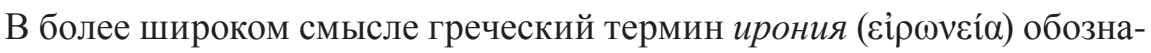
чает, как известно, «насмешливое притворство», и обычно представляет собой некое высказывание, в котором утверждаемое противоположно по смыслу тому, что непосредственно произносится. Особый подвид чисто русской автохтонной иронии известен как «стёб», разговор о котором следовало бы вести отдельно. В понимании А. Ф. Лосева, ирония - это «когда я, желая сказать “нет”, говорю “да"», но при этом и «не скрываю своего “нет”»13. Слово «ирония» в античности связывали с базовым греческим глаголом вір $\omega$ - 'говорить' (см. Лосев 1966: 55-57; Elleström 2002: 37), хотя у этой этимологии есть свои трудности (Chantraine 1968: 326). Лосев указывал также на то, что глагол вир чения обряда заговора, а это, в свою очередь, могло привести к пониманию عíp блуждение других. У высоко ценимого Лосевым Платона ирония приобретает позитивное измерение, как бы исподволь служа опровержению ложного знания и ложного пафоса. Важно, что у Сократа ирония принципиально проистекает от своеобразно понимаемой маевтической любви 14 к мудрости и ставит под сомнение всякую - и чужую, и собственную уверенность в обладании окончательной интерпретационной истиной. Напомним о словах самого Сократа, дошедших до нас через посредство внимавшего ему Платона, и цитируемых в латинских перифразах «scio me nihil scire» или «scio me nescire» («я знаю, что ничего не знаю»). Отзвук этого иронического афоризма мы далее находим у апостола Павла в Первом Послании к Коринфянам (8:2): «Кто думает, что он знает что-нибудь, тот ничего еще не знает так, как до́лжно знать». О сократическом специфическом юморе в сравнении с христианской парадоксальной мыслью в этой связи проникновенно писал в свое время Владимир Соловьев (Соловьев 2017: 596).

Русский мат предоставляет поистине бескрайнее языковое поле для изучения гротескной полисемии, сложных двусмысленностей и разного рода абсурдной иронии в самых клинических ее вариантах. Ирония как бы всегда незримо сопутствует узусной жизни того или иного экспрессивноидиоматического русского выражения, придавая русскому мату особые и неповторимые черты. Примечательной чертой русского мата является как раз его невероятная многозначность, радикальная полисемия. Процесс ее развития начинается с двусмысленностей, заложенных во многих обс-

13 Ср.: «...ирония возникает тогда, когда я, желая сказать “нет”, говорю “да”, и в то же время это “да” я говорю исключительно для выражения и выявления моего искреннего “нет”. Представим себе, что тут есть только первое: я говорю “да”, а на самом деле думаю про себя “нет”. Естественно, это будет только обманом, ложью. Сущность же иронии заключается в том, что я, говоря “да”, не скрываю своего “нет”, а именно выявляю его. Мое “нет” не остается самостоятельным фактом, но оно зависит от выраженного “да", нуждается в нем, утверждает себя в нем и без него не имеет никакого значения» (Лосев, Шестаков 1965: 326-327; ср. Лосев 1966: 79).

14 Прилагательное $\mu \alpha \imath \varepsilon \tau \imath \kappa o ́ s$, которым у Платона описывается сократическое искусство, отсылает к повитухе, осторожно выпестовывающей телос мысли. 
ценных словах и выражениях. Первоначальная «лексико-тематическая группировка» русской бранной лексики была предложена в ценной работе В. М. Мокиенко (1994). С тех пор появилось немало новых и уточняющих этот вопрос лингвокультурологических штудий ${ }^{15}$.

\section{2.}

Относительно простым и ясным примером пути семантического «одвусмысливания» является (просторечно-)частотное русское слово блядь. Древнерусский и церковнославянский глагол блмсти (1 л. ед. ч. бладж, 3 л. ед. ч. блмдетъ), связанный с концептами «ошибки, заблуждения и лжи», имел значения 'заблуждаться', 'пустословить' (как ни соблазнительно было бы предположить обратное, но всем известное международное присловье «blahblah-blah» связано с ним лишь паронимически) ${ }^{16}$, а также 'лгать', и 'развратничать' ${ }^{17}$. Соответственно, у производного от него существительного блмдь, имевшего значения 'заблуждение', ‘пустословие' и 'ложь', параллельно развивалось значение 'развратница' (ЭССЯ 1975, 2: 114-115). «Выявленные значения слова “блядь” в языке русского средневековья» проанализировал А. Юрганов: «это сложная контаминация, структурные компоненты которой — “ложь” [блуд и ошибка - Д. И.], “ересь”, “распутная женщина”» (Юрганов 2000: 195-196). «Блядь» как языковой концепт, таким образом, начиналась как референция «лживой ошибки», но далее трансформировалась в развратницу, а затем и попросту в экспрессивное идиоматическое междометие бля.

Протопоп Аввакум в своем послании царевне Ирине Михайловне Романовой (1666-1667) говорит о никонианстве: «Преудобренная Невесто Христово, не лучши ли со Христом помиритца и взыскать старая вера, еже дед и отец твои держали, а новую блядь в гной спрятать» (Малышев 1958:

15 В. И. Жельвис обособляет 27 самостоятельных функций обсценно-экспрессивной лексики (вне структурно-значимого разделения на первичные, вторичные или «дополнительные» функции); см. Жельвис 2001: 121 (ср. также Левин 1986). Ситуативная функциональность матерных выражений последовательно фиксируется в словаре А. Н. Баранова и Д. О. Добровольского (Буй 2005). Об обсценном аспекте русской топонимии (где присутствует реальная российская деревня Елда (Угличский уезд) или местечко Залупинщыь (Вяземский уезд), где сущствует деревенька Поиблица, местечко Поиблой починок, и где текут небольшие речки Блядейка, Еботенка, Мудовка, Наебуха и Пиздюрка) см., в частности, Назаров 1999.

16 «Idle, meaningless talk, probably imitative or echoic in origin» (Grillo 1989: 174). Как отмечает британская Би-би-си со ссылкой на OED: «The Oxford English Dictionary credits the first documented use of 'blah' to American journalist Howard Vincent O'Brien, in his 1918 memoir Wine, Women \& War - “[He] pulled old blah about 'service'..." Then three years later, the US magazine Collier's: The National Weekly used a double blah — "Then a special announcer begin a long debate with himself which was mostly blah blah" " (Who, What, Why: When did we start saying ‘blah, blah, blah'? BBC.com, 07.05.2014. http://www.bbc.com/news/blogs-magazinemonitor-27300184).

17 Праславянский корень восходит к и.-е. ${ }^{*} b^{h} l e n d^{h}$ - (базовое значение - «смешивать»); для сравнения: потомки этого корня в современном английском - blend («смешивать; смесь») и blind («слепой»). См. Kroonen 2013: s. v. 
417). В «Слове о рогатом клобуке» Аввакум сообщал городу и миру: «Я еще даст Бог преж суда тово Христова взявше Никона разобью ему рыло. Блядин сын, собака, смутил нашу землю. Да и глаз те ему выколупаю, да и толкну ево взашей» (Малышев 1958: 420). И было за что: «Яко блудница, так и римляне и греки с никонияны, Василия Великаго предание - клобук с себя скинув и здели рогатой: лице все свободно стало, расчесав власы не мешает за бляднями ходить, целоватцо» (Там же). В пятой челобитной царю Алексею Михайловичу (1669 года) Аввакум пишет: «Что есть ересь наша или кий раскол внесохом мы во Церковь, якож блядословят о нас никонияня, нарицают раскольниками и еретиками <..>?» (Аввакум 1960: 196). «Богородицу согнали со престола никонияне-еретики, воры, блядины дети», сетует протопоп в толкованиях на псалмы (Аввакум 1960: 152).

В Акафисте Богородице поется (Кондак 6, «Проповедницы Богоноснии быша волсви...»): «...оставиша Ирода яко блядива». По указанию митрополита московского Филарета в письме к обер-прокурору Священного Синода графу А. П. Толстому от 17 марта 1860 г. прилагательное «блядива» было заменено на «буесловяща» (Попов 1903: 92-93; Живов 1996: 508). «Слово сіе имъетъ нынъ новое позорное значеніе», — аргументировал свое решение Филарет (Там же: 93; Филарет 1886: 510). Ср. преломление самой знаменитой анафемы начала XX столетия в стёбной стилизации А. И. Куприна («Анафема», 1913): «Протодіаконство твое да благословитъ Господь Богъ нашъ, анаөемствовати богохульника и отступника отъ въры Христовой, блядословно отвергающаго святыя тайны Господни болярина Льва Толстого. Во имя Отца, и Его Сына, и Святаго Духа» (Куприн 1920: 156).

Древние еврейско-христианские источники убеждают в том, что стремление избежать паразитических обсценных ассоциаций, коим был подвигнут митрополит Филарет, возникало в истории христианства не раз. Даже Апостол Павел сменил свое изначальное имя, чтобы избавиться от ненужных профанных смыслов. При чтении «Деяний Апостолов» становится понятно, почему Савл (Шауль Тарсийский) 18 отказался от своего природного еврейского семейного имени и приобрел римский номен «Павел».

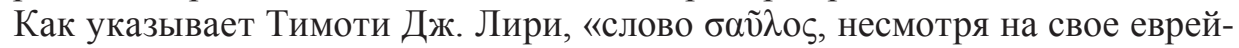
ское происхождение, имело также общеизвестное в эллинистическом мире греческое узусное значение, мимо которого обычно проходят все комментаторы: слово это использовалось для описания расхлябанной и развратной походки проституток <...>. Верховный посланец Единственной Правильной Веры к грекам, он вряд ли мог рассчитывать на успешную религиозную миссию, нося имя “имеющий задницу блудницы”»119. Таким образом, отход

18 Апостол Павел (изначально Шауль: ивритское слово שאול означает «взятый напрокат», но также «выпрошенный, вымоленный») — Саул из Тарса (Киликия), Савл Тарсянин, сформулировавший важнейшие канонические установки Церкви по вопросам сексуальности и телесности.

19 «...the word $\sigma \alpha \tilde{v} \lambda \mathrm{s}$, despite its Hebrew origins, has also a Greek application well recognized in the Hellenistic world, albeit generally ignored by commentators, being used to describe 
от имени «Савл» становится яснее: русским эквивалентом греческого «Савл» было бы что-от вроде «Блядожоп» - имя, ни в коей мере не подходящее для Отца Церкви и духовного подвижника.

Процесс смешения блядства как ереси-ошибки-заблуждения и телесного разврата происходил уже в самом начале бытования (древне)русского литературного языка. Так, один из основоположников юродиво-церковного стёба, уроженец Переяславля XII века, пришедший из Орды «с мешком зелия» и далее безжалостно сосланный баснословным основателем Москвы Юрием Долгоруким на Архангельское озеро Лача, Даниил Заточник ${ }^{20}$ указывал: «Девиця погубляет красу свою бляднею, а мужество татьбою [т. е. кражей]» (цит. по Романов 1966: 20). Голозадая блядь-развратница осмыслялась как забывшая или оставившая путь Истины, путь правильной божественной жизни, по сути, как и «блядословы-еретики».

Феликс Дрейзин и Томас Пристли в своей замечательной первопроходческой статье говорят о русском мате как о невероятно богатой (ехсерtionally rich) лингвистической функциональной системе особого рода (Dreizin, Priestly 1982: 233). Они же говорят об особой грамматике русского мата, а также, добавим мы, результирующей семантики и прагматики. Особая структура матерного прагма-узуса порождает своеобычную эстетику мата, связанную с привлечением нового способа понимания окружающей реальности ${ }^{21}$. Авторы создали крайне релевантную и по сей день таблицу основных опорных пунктов матерного узуса, служащую хорошим примером также и грамматически обусловленной полисемии.

Изучение вопросов исторической семантики и происхождения русского мата было в свое время положено Б. А. Успенским в классической работе «Мифологический аспект русской экспрессивной фразеологии», тезисы которой были опубликованы в Москве в знаменитом сборнике Структура текста - 81 (1981); в полном виде она появилась позднее в Studia Slavica Hungarica 22 . Успенский оправданно предлагал осмыслять феномен русского мата в аспекте анти-поведения, обуславливающего радикальное нарушение различных культурных запретов. Он также раскрыл соотнесенность

the loose and wanton gait of prostitutes. $<\ldots>[\mathrm{A}] \mathrm{s}$ chief emissary to the Greeks of the One True Faith, he could not hope for a successful ministry if he sported a name like 'slut-arsed'» (Leary 1992: 467). Отметим, что судя по всему апостол имел два разных имени: он не оставлял своего еврейского имени Савл (Шауль), но как римский гражданин имел при формальной записи рождения и латинское имя - это имя и было Павел: «Но Савл, он же и Павел, исполнившись Духа Святаго...» (Деяния 13:9). См. также важную работу гарвардского исследователя: Harrer 1940.

20 Само примечательное слово «Заточник», возможно, было «особо заточенным» криминально-смысловым прозвищем, которое в теории могло означать наказанного - заключенного, сосланного в глухомань человека. Данилово «заточение» на Лаче-озере оказывается здесь релевантным, как и вся биография его как писателя и человека «заложившегося», т. е. по сути согласившегося на некую подневольную работу в качестве залога своей жизни.

${ }^{21}$ См.: «...generates in mat an aesthetic function: namely, the 'acquisition of reality'» (Dreizin, Priestly 1982: 234).

22 Цитируем здесь по более доступной отечественной перепечатке Успенский 1994. 
мата с языческим культом. В частности, некоторых славянских языках глагол, восходящий к праславянскому *jěbati, «может выступать в значении 'проклинать'», в чем исследователь усматривает «следы ритуального употребления матерщины» (Успенский 1994: 64; см. также Рождественский 1902). Согласно изысканиям Успенского, по своему первоначальному смыслу и предназначению матерная брань была не оскорблением, а заклятием и проклятием ${ }^{23}$. Реконструируя субъект и уточняя объект главного матерного выражения «...ёб твою мать», исследователь приходит к выводу, что в основе его лежит образ осквернения матери-земли нечестивым псом, которая, в свою очередь, представляет собой травестию мифологического брака неба и земли (Успенский 1994: 86 и далее). Пес-осквернитель (экс-трикстер) продолжает жить в славянских идиомах — таких, как русское сукин сын или польское psia krew (собачья кровь, собачье отродье) ${ }^{24}$.

Пес воспринимается как существо телесно нечистое и в пределе как средоточие инфернальных нечистот ${ }^{25}$. В мусульманской традиции собак запрещено держать в человеческом жилище. Если в православный храм забегает собака, его, по правилам, полагается переосвятить как оскверненный. Примерно так же описывается четвероногий друг и в христианских мифологемах, где следует обратить особое внимание на блок сюжетов о песьеглавцах как диких обитателях запредельных стран; киноцефалом представляли святого Христофора и соответственно изображали его на иконах ${ }^{26}$. Пес репрезентирует бездуховное дикое язычество или иноверие, он может дать поведенческий ход любому неприемлемому с точки зрения канонической церковной жизни «непотребству». Отсюда возникает и идиоматика непотребной, запретной и двусмысленной «ебли по-собачьи», которая ретуширует грань между скотским и человеческим. Во многих христианских культурах (от средневековья до современности) регламентирован запрет на соответствующую позу. Первоначально она интерпретируется как языческая, а затем стигматизируемая как неестественная, свойственная не людям, а животным, и противопоставляется разрешенной для санкционированного секса «миссионерской позе».

23 Отметим, что сам глагол в его буквальном значении с самого начала своего исторического узуса значил то же, что значит в русском и сейчас. Родственный ему глагол в том же значении и мало отличающийся по форме был уже в ведическом санскрите (yábhati).

24 Вся эта ситуация по сути означает ритуальную формулу унижения, где метафорический пес олицетворяет говорящего человека: я ёб твою мать, т. е. я по факту твой Господин и Отец (или точнее - «я из поколения твоих отцов», тех, перед кем ты должен склониться), так что «молчи и повинуйся». Сексуальные коннотативные знаки всегда служили орудием брутального подчинения у приматов (например, у павианов). Как указывают исследователи, еще в древнеиндийском законодательном тексте «Архишастра» среди примеров наказуемых оскорблений присутствует дословно «я взойду на твою мать» - точный эквивалент русского выражения. (Сообщено в устной беседе Алексеем Юдиным и Леонидом Куликовым). Поскольку собаки весьма похотливы, то именно они в народном сознании репрезентируются как фигуративные знаки «грязного секса-унижения».

25 О чистых и нечистых животных см. фундаментальное исследование: Гура 1997. O собаках в русской литературной культуре см. нашу обзорную статью Ioffe 2016.

26 Об отражении этих мотивов в авангардном русском искусстве см. Иоффе 2016. 
Сам по себе концепт глагола ебаться и его экспрессивно-фразеологические производные выступают как ценный пример абсурдной многозначности всей корневой матерной системы русского языка. Глагол ебать(ся) и производное от него существительное ебля означают процесс коитуса. Однако слово ёбнуть в современном языке уже означает 'больно ударить'. Пассивное причастие ёбнутый - буквально 'ударенный', pendant вульгарно-разговорному «чокнутый», содержит в семантическом анамнезе представление о человеке, активно кем-то «трахнутом» ${ }^{27}$. Рефлексивная форма того же глагола (ёбнуться) может отсылать к целому ряду понятий. Сразу вспоминается характерный пассаж из Сергея Довлатова, передающий в литературном тексте разговорный эпизод, которому он был свидетелем:

Прислали к нам сержанта из Москвы. Весьма интеллигентного юношу, сына писателя. Желая показаться завзятым вохровцем, он без конца матерился. Раз он прикрикнул на какого-то зека:

— Ты что, ебну́лся?! (Именно так поставив ударение).

Зек реагировал основательно:

- Гражданин сержант, вы не правы. Можно сказать - ёбнулся, ебану́лся и наебну́лся. А ебну́лся - такого слова в русском литературном языке, уж извините, нет...

Сержант получил урок русского языка. (Довлатов 1999: 87).

Один и тот же корень реализуется во множестве лексем (самых разнообразных, но не любых: есть правильные и неправильные), которые приобретают множество значений (самых разнообразных, но не любых: есть употребительные и не употребляющиеся). Мат многозначен, но ситуативно полностью понятен. В этой связи на ум приходит давнишний «русско-матросский» каламбурный вопрос о том можно ли произнести на русском языке целую фразу, в которой все слова были бы с одним корнем? Да, можно. Что сказал русский боцман, когда увидел, что его баржу слишком перегрузили? - Он сказал дословно: «Нахуя дохуя нахуярили? Расхуяривай нахуй!». Эта фраза, эксплицирующая и экземплифицирующая многозначность русской экспрессивной идиоматики, могла бы стать эпиграфом к нашей статье 28.

Персонаж из довлатовского армейского фольклора не включил в деривационный ряд специфичный глагол, образованный от стандартной формы выебать ('вступить в активную половую связь') — «выебнуться», означа-

27 Существует, по по-видимому, общеевропейская семантическая модель обозначения ненормального, сумасшедшего как «ударенного». Pété во французском языке, stuknęty — в польском, чокнутый (собственно, 'ударенный', см. ЭССЯ 1977, 4: 141) и прибитый в русском. Отметим также, что péter означает и 'стучать', и 'пукать', а в польском pukać означает 'стучать'. Возникает метафорическая ассоциативная связь стучания и пукания (сходство по звуку) и стучания и ебли (сходство по характеру движения). При этом общепольский «пёрун» и славянский верховный бог грома Перун и полуобсценный русский глагол пердения-пердежа находятся уже в более «полисемантических» отношениях.

28 Ср. в песне С. Шнурова «Машина» (2014): «Нахуя хуярим? - /Нихуя не ясно,/ Охуевшим харям, / Дохуя опасным...»). Разбор композиции см. в статье Россомахин, Замятина 2020. 
ющий успешную (или не очень) попытку выделиться или прославиться 29. От этого же глагола образовано и важное стёбное существительное выебон ${ }^{30}$. Родствен ему издевательский «наебоз» или «наебон» как особый вид обмана или опять же брутального стёба; оба существительных образованы от глагола наебать ('обмануть, провести') 31 .

Семантические вариации главного «футуерального» глагола этим не исчерпываются. Так, подъебнуть означает 'иронически уколоть' ${ }^{32}$, а $н$ ебениться - 'напиться' (ср. напиться в зюзю, в доску, в свинью, в жопу, в сраку), т. е., выражаясь нематерно, «нажраться» или «надраться». Драть как эвфемизм к ебать позволяет выстроить ряд последовательной дисфемизации: напиться $\rightarrow$ нажраться $\rightarrow$ надраться $\rightarrow$ наебениться.

С глаголом ебаться и отглагольным существительным ебля связано и суффиксальное производное еблище, образованное грамматико-звуковым обманчивым способом по образцу существительных с суффиксом -ищ-, означающем, при добавлении к основе глагола, 'место, характеризующееся действием, которое названо мотивирующим глаголом' (собственно, вместилище, а также токовище, толковище, бензинохранилище, седалище и т. д.), а при добавлении к основе существительного - либо 'место, где находился или находится предмет, названный мотивирующим существительным' (городище, пепелище, узилище, туловище), либо 'предмет, обладающий некоторым свойством в превосходной степени (арбузище, болотище, человечище, умище и др.). При этом словом еблище обозначается женская вагина - влагалище, т. е. место, в которое можно влагать ('вставлять') уд; однако суффикс -ищ- одновременно намекает на якобы огромную величину описываемого предмета ${ }^{33}$. Другим отглагольным существительным из того же гнезда, является ебало, которое означает не только 'рот' (паронимически, хлебать // хлебало $\rightarrow$ ебать// ебало), но и (метонимически) человеческое 'лицо' в целом (синекдоха: pars pro toto). Однако начистить ебало не означает *'помыть рот или лицо', но сообщает о брутальном «набитии морды лица» (ср. также въебать/уебать 'ударить').

Чем отличаются друг от друга следующие крайне двусмысленные слова-термины: еблан, уебан, ебанат и ебанько? Между ними имеется семан-

29 Эти слова производятся по аналогии изменением нематерных экспрессивных форм типа выпендриться/выпендриваться, выкаблучиваться, выдельваться. Имеются словообразовательные модели с устойчивым грамматическим значением, и корневые вакансии в них заполняются матерными корнями; можно выстраивать параллельные списки таких выражений. Вышеприведенная фраза боцмана именно потому кристально ясна, что понятны приставочно-суффиксальные модели в ней.

30 Ср. Выпендреж от выпендриваться, выдельвание от выдельваться.

31 Ср. с разговорными наколоть, надурить. У глагола обмануть есть матерный эквивалент объебать (стой же приставкой об-). Мат выступает как словообразовательное зеркало обычной экспрессивной речи, что представляет из себя хороший сюжет для возможной «чисто-лингвистической» будущей более объемной работы.

32 Ср. подколоть ('подшутить над кем-л.').

33 В этой словообразовательной модели суффикс может означает нечто большое и при этом негативно воспринимаемое или страшное: чудовище, домище. Ср. также слово уёбище, в котором уже нет семантики «величины», но имеется резко негативная коннотация. 
тическая нюансировка границы; так, в частности, еблан означает просто глупого и неудачливого человека. Поэтому, скажем, псевдоним российского поп-певца Димы Билана (урожденного Беланом), рифмующийся с ебланом (а также с бедламом) трудно считать столь уж удачным. В это же время укажем, что «уебан» ${ }^{34}$ - это просто лузер, родственный «мудаку» ${ }^{35}$. Eбaнam, как и его близкий семантический родич ебанько, выступает психически неадекватным или даже клинически нездоровым персонажем. Не совсем понятно, как в этом гнезде завелся императив «ебанись!», который является призывом не к тому, чтобы что-либо сделать, но как раз наоборот - остановиться и не делать ${ }^{36}$.

Многосерийное и многослойное полисемическое создание матерных слов с помощью префиксации и суффиксации описано в статье Дрейзина и Пристли:

The concatenation of a basic mat verb with any of the listed prefixes [do-, is-/ iz-/izo-, na-, nad-/nado-, nedo-, o-/ob-/obo-, ot-/oto-, pere-, pri-, pro-, po-, pod-/ podo-, ras-/raz-, s-/so-, u-, v-/vo-, vy-, vs-/vz-, za-] produces a verbal form that can be used in a given relevant context $<\ldots>$ :

doebát', doebát'sja, dopizdit', dopizdit'sja, doxujnút', doxujáči', doxujáčit'sja, iz"ebát', iz"'ebát'sja', ispizdit', isxujnút'sj', izobzdét'sja', nabzdét'sja', naebát'sja,, naebnút'sja', napizdýkivat', naxujákat'sja', naxujnút'sja', naxeráčivat'sja, naebát', nadobzdét'sja, nedoebát', nedoebát'sja, nedoperdét', nedoxujáčit', v'ebát', v'ebát'sja, vpízdit'sja, vpizdit', vxujáčit', vxujárivat'sja, vpizživat'sja, vozbzdét', vpizdýkivat', vxujáknut'sja', vxujnút'sja, výbzdet', výebnut'sja, zaebát', zaebát'sja, zaxujáčit', zaxujáčit'sja, zapizdýčit', zaebistósit', ... (Dreizin, Priestly 1982: 238, с исправлением опечаток)

Матерные слова в тех или иных своих формах образуются «по цепи» значений своих различных ядер-этимонов. При этом неясно, как семантически соотносится слово хуйня, означающее 'чушь, бессмыслицу, ахинею', с вроде бы параллельным ему образованием пиздец̧37, означающим 'полную

$34 \mathrm{Cp}$. также уёбок, уебище - более ранние образования, чем уебан. Сам же уебан обрел культурную значимость одноименного «индийского» трансгрессивного клипа Сергея Шнурова (2014): «...У него очки Ray-Ban/ и штаны за-у-же-ны, / Он - за-ба-вный уе-бан, / в голо-ву конту-же-нный...». См. https://www.youtube.com/watch?v=jUZO0zpHhOA

35 Этимология частотнейшего русского многозначного слова мудак до сих пор неясна вполне, о его происхождении см. с. 721-723 наст. изд. «Мудак» - хоть и недалек, и отчасти глуп (ср. салтыковский «органчик»), — может иметь начальственную силу и крайне высоко располагаться в людской иерархии. (По иронии межъязыковой игры, в современном иврите слово «мудак» с твердым конечным «к/г» означает 'человека, крайне встревоженного своей непростой судьбой'). Вместе с тем уёбок - это низшая человеческая каста, это, по сути, «неприкасаемьй», разновидность тюремного «петуха» (возможно, с аналогичной мотивировкой снижения социальной роли).

36 Ср. императивно-оценочное суждение-восклицание «заебись!», в реальной семантике которого никакого следа императивности не осталось.

37 Эти слова, образуя четкую дуалистическую семантическую пару, при этом не являются противоположными по смыслу. То же относится и к рядам их эвфемизмов: херня, хреновина, хренотень... vs. писеи/песеи, капеи, звездеи, пипец. Слова, образованные по распространенным деривационным моделям путем подстановки матерного корня, сами потом становятся структурно-семантическими моделями для образования дальнейших эвфемиз- 
всеобщую катастрофу' и неминуемый конец, по отношению к которому оно является паронимическим дисфемизмом ${ }^{38}$. «Пиздеи» (со своими слабомаскировочными эвфемизмами «звездецң», «пипец» и «трындец»)39 выступает как нечто предельно многозначное, не поддающееся никакому логоцентрическому описанию или сравнению, из ряда вон выходящее, неимоверное, исключительное по силе или степени гротескного проявления (cp. Левин 1986: 72). Примечателен дуально-амбивалентный характер «русского пиздеца» - это оценочная характеристика чего-либо как чего-то невероятно примечательного, превосходного, прекрасного («это просто пиздеи как заебательски»), но также и чего-то очень плохого, тяжелого, непреодолимого («ну всё, пиздеи тебе, уёбок»). При этом слово это также используется и для выражения крайнего, предельного удивления («смотри, какая жопа! пиздеи!»).

«Пиздец» является очевидным дериватом пизды. В этом отношении очень любопытна возможная этимологическая связь между словами пизда и пёс, о которой писал в свое время Б. А. Успенский ${ }^{40}$. В современном языке в качестве отсылки к этимону пиздеца вместо «злоебучего» $n c a$ может использоваться пушной северный зверь песеи. В литовском языке, как указывает Успенский, имеется слово pisus ('fututor' собственно, ёбарь, в современном языке - 'распутник'), а для более древнего состояния «восстанавливается также форма *pisùs со значением 'склонный к совокуплению', ср. дошедшие до нас формы с осложнением основы: pisnùs, pislùs 'распутник; тот, кто часто мочится'» (Успенский 1994: 98)41. Литовскому *pisùs может соответствовать слав. *pisŭ (пьсъ). Таким же образом, по Успенскому, «объясняется и употребление слов кобель и сука в значении 'распутник' и 'распутница' в современном русском, которое отвечает значению слова pìzius в современном литовском» (Там же) $)^{42}$. Узус этих слов иронично амбивалентен. Как представляется, богохульство русского мата неразрывно связано с его семантической радикальной амбивалентностью (что представляет уже отдельную тему для размышления, которую мы разовьем в отдельной работе).

Некоторые примеры двусмысленных абсурдностей русского мата можно найти уже в самых ранних берестяных грамотах. Так, например,

мов. Процессы эти начались не позднее XIX века: многие эвфемизмы с «хер» датируются временем до последней реформы алфавита, отсылая к старому названию буквы $X$.

$38 \mathrm{Cp}$. также далеко отстоящее семантически, но всё же связанное с «пиздещзо» паронимически выражение «лососнуть туниа», а также ряд отчасти абсурдных отглагольных обсценно-экспрессивных форм: «Былдани сосияа, хуйло»; «Въеби говнеца»; «Блядни ебарьиа» и т. д.

39 В данном случае это эвфемизмы, сохраняющие финаль замещаемого слова. Не менее обычны эвфемизмы, сохраняющие начало ругательства с заменой, такие как блин или бляха-муха. Ср. во французском рuré вместо putain, в польском kuchnia/kurcza вместо kurwa.

40 Другая этимология увязывает слово пизда со словами гнездо и седло - как 'то, на чем или чем сидят' (ЭССЯ 1979, 6: 172).

41 Cp.: «*pisbda - 'мочеиспускательный орган'» (Мокиенко 1994: 62).

42 См. также (старо)франц. pisser и его итальянский эквивалент. 
новгородская грамота № 330 (ХІІІ век), обнаруженная в конце 1950-х годов, представляет из себя рифмованную дразнилку, которая переводится так: ‘гузка (задница?) ... ебет другую, задрав одежду'. Как указывает А. А. Зализняк, автор грамоты «использовал эффект непристойности», как бы зримо «помноженный на эффект клинического абсурда» (Зализняк 2000: 99-100).

В грамоте из Старой Руссы № 35 (ХІІ век), в конце записки от некоего Радослава к некоему человеку с примечательным именем Хотеслав, после просьбы взять у торговца деньги, другим почерком приписано: «АковебратеебилежА» («Акове, брате, еби лежА!»). Возможный смысл этой пометки - 'Яков, брат, «не оригинальничай», «будь как все»'. Дальше по адресу Якова прибавлены еще два замысловатых ругательства: «ебехота», т. е. 'желающий совокупления (?)', и «аесова» — 'сователь яйца', причем эти оскорбительные слова, возможно, являются смеховой анаграммой имени Хотеслав (Янин, Зализняк, Гиппиус 2004: 117-118, 228-229).

Имеется также знаменитая грамота из Новгорода под № 955 (XII век) которая представляет из себя лично-интимное письмо от свахи Милуши к некоей Маренке (Марене) - новгородской знатной матроне (документ обнаружен в 2005 году). Сваха Милуша сообщает, что мол пора бы Великой ('старшей') Косе (возможно, дочери Марены) пойти наконец замуж за человека с интересным онейроидным именем «Сновид». Текст «пеи пизда и ськыле» должен означать: 'пусть вульва и клитор пьют' (Зализняк, Янин 2006: 8-12). Напоение вульвы упоминается в различных «срамных» частушках, исполняемых во время свадьбы для усиления благоприятных семейных событий, где «сохраняет свой первоначальный сакральный и ритуальный характер» (Там же: 11). Мотив сохраняется в современных частушках:
Шла матаня из гостей, У реки разделася.
Пей, пизда, холодну воду:
Колбасой объелася.
Через речку перешла,
На бережочек села.
Кунка, пей, пизденка, пей,
Колбасы поела.

(Топорков 1995: 483-484)

Необозримое поле русского народного мата, ныне отчасти доступное в книжных критических изданиях, предоставляет немалые возможности изучения границ языкового абсурда и разного рода парадигмальных обсценных двусмысленностей:

У ворот девка стояла,

Кулаком в манду пехала,

Увидала ее мать

И давай ее ругать: 
- Зачем, дура, зачем, блядь,

Кулаком в пизду пехать?

Продай шубку, купи хуй,

Кулаком в пизду не суй!

(Топорков 1995: 508)

Однако здесь элемент абсурда еще ограничен смысловой канвы прагматики и остается хотя бы относительно семантически прозрачным.

3.

Двусмысленная абсурдность радикального иронического эротизма русского мата видна во многих стихотворных текстах русской литературы классического периода - достаточно вспомнить Ивана Баркова и его последователей, чьи сочинения составили сборник Девичья игрушка, или поэмы Пушкина Тень Баркова и Царь Никита. Вот, например, масштабное прославление восхода и заката как гаргантюанского полового акта из порнографического бурлеска XVIII века. В бурлескной «Оде Пизде» Михаил Чулков (если это был он, ибо авторство текстов из Девичьей игрушки доподлинно неизвестно) крайне амбивалентно воспевает начало дня и его конец:

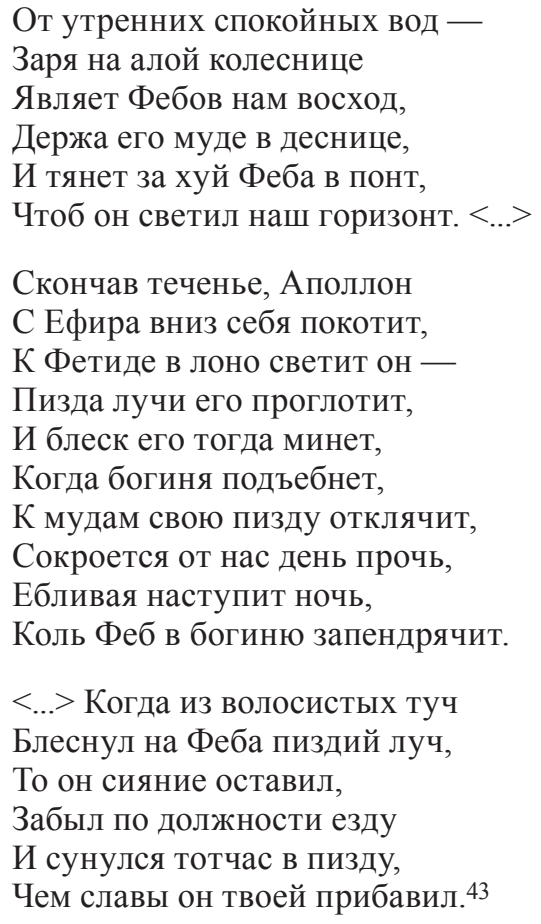

43 Цит. по: Шапир 2015: 67. Ср. Барков и др. 1992: 45-50. 
Важно еще раз подчеркнуть, что русский мат переполнен необычными идиоматическими конструкциями, стимулирующими некую семасиологическую туманность конечного смысла. В XX веке гнездовой концепт «пизда» в полной мере реализует эту потенцию. В ряду разнообразных идиоматизмов (идио-матизмов) чрезвычайно любопытна идиома «без пизды»». Мы встречаемся с этим выражением в сверхпопулярной современной иронико-стёбной песне Сергея Шнурова «Экспонат» (2016) ${ }^{44}$. Согласно сервису YouTube, за пять с половиной лет эта песня-клип была просмотрена 175 миллионов раз. Там имеется такой куплет:
...Мы с Генкой и Маринкой
Ходили в «Мариинку»
Послушать чиста Глинку,
Партер, туды-сюды.
Там сразу без заминки
В партере «Мариинки»
Все поняли блондинки -
Я прима, без пизды!

Речь, понятно, не идет о том, что у главной героини — той, что гуляет в «охуительных штанах», нету вовсе ни вагины, ни клитора. Согласно материалам А. Ю. Плуцера-Сарно, выражение «без пизды»» «употребляется как вводное словосочетание со значением клятвы, заверения в правдивости слов: 'честное слово, клянусь'»; примеры: «Не нужно мне кроватей и диванов: / Я, без пизды, с тобой навек останусь <...> (Мякишев, Чернолузский. Без пизды)»; «— Ладно, будешь ты моей невестой. / — Правда? - Без пизды! (Сектор Газа. Кащей Бессмертный)» (Плуцер-Сарно 2005: 151). Без пизды говорю (ср. в блатном арго аналогичный перформатив: зуб даю), без пизды (= не вру, ей-богу, чистая правда) - имеется в виду подтверждение достоверности, истинности каких-либо высказываний (Там же).

Но почему бытование без пизды оказывается гарантией правдивости высказывания? Почему отсутствие вагины и сопутствующих ей органов (медико-обсценный термин пизда означает влагалище, половые губы плюс находящийся по соседству клитор) ${ }^{45}$ должно сообщать о какой-то особой

44 См. видеоклип: https://www.youtube.com/watch?v=et281UHNoOU

45 Семантический и стилистический аналог русской пизды, английское слово cunt (возможно, родственное латинскому сunnus с тем же значением) восходит к прагерманскомy *kuntō. Ближайшие параллели к английскому слову имеются во всех других германских языках (древненорв., исл. и шв. kunta, соврем. норв. и дат. kunte, ср.-н.-нем. kunte, ср.-в.-нем. kunt, и т. д.). Индоевропейские истоки прагерм. *kuntō, как и лат. cunnus, неясны. Одна, более убедительная, этимология ведет к и.-е. *gwen- (базовое значение 'женщина'; корень, к которому восходят, в том числе, греч. үvvи́, праслав. *žena > рус. жена и прагерм. *kwenō//*kwēniz > англ. quean//queen), другая, менее убедительная, - через возможное родство с лат. cutis ('кожа') - к и.-е. *(s)kewH- ('покрывать'). Известна английская поговорка, зафиксированная уже в анонимном сочинении XIV века «Притчи Хендинга»: «Geue pi cunte to cunnig and craue affetir wedding»' 'give thy cunt cunningly and make demands [crave] after [your] wedding', ‘дай прихотливо пизду и требуй что хочешь после свадьбы' (OED 1989: 130; Rees 2013: 18). Примечательно что английское слово cunt широко употребляется 
жизненной правде? Что вообще плохого в пизде и ее наличии? Или, противоположным образом, что хорошего в ее отсутствии? Очевидно, выражение «без пиздыl», означающее ‘без вранья, без пустословия', заимствовало свою семантику у глагола пизде́ть ' 1 . пустословить, говорить без умолку; 2. лгать'. Возможно реконструировать деривационную цепочку: пизде́ть $\rightarrow$ пиздёж $\rightarrow$ без пиздежа $\rightarrow$ без пизды.

Таким образом, словосочетание «без пиздыl» функционирует как экспрессивная идиома, снимающая изначальное семантическое значение 'женского полового органа'. Точно так же ведут себя выражения «дать/nолучить пиздыl». В аналогичной цепочке отпиздить $\rightarrow$ дать пиздюлей $\rightarrow$ дать пизды каждое звено означает 'побить'. Соответственно, «получить пизды » вовсе не значит получить ее в свое пользование, - наоборот, это значит получить больные удары и тумаки, тяжелые удары судьбы. Как пел рок-поэт Егор Летов, подчеркивая иномирную кармическую семантику получателя пизды: «Я устал получать пизды, / Я рыдаю от ваших речей, / Я желаю стать стаей грачей / Я хочу умереть молодым» (1984; цит. по: Андреева 2012: 345). В обоих случаях слово пизда получает новое значение от вторичных, образованных о нее слов, и полностью утрачивает исходное материальное значение.

в технических терминах разных отраслей профессиональной деятельности и активно использовалась уже в раннем английском средневековье (Baker, Holt 2001; см. также: Grose 1788: s. v. "C**t": “a nasty name for a nasty thing”). В английском морском деле используется понятие cunt splice ('пиздячий сплесень'); это один из видов сращивания (splice 'сращивание, средостение, сплесень, сросток' ) веревки, использующийся для коррекции неправильного присоединения двух линий на кораблях (Falconer 1780: s. v. "Splice"), где cunt в современном употреблении заменяется для благозвучия на сut 'отрезанный'. В в типографской печати с литых форм использовался специальный термин cunt lead ('пиздячий шпон'), где lead (шпон) - это свинцовая пластина. У американских военных имеется мягкая шляпа, у которой есть складка: cunt cap. В современном русском этот шляпный концепт известен как мягкая «пилотка». Здесь напрашивается известная армейская идиома «сними пизду, надень пилотку», связанная с табу на ношение пилотки с по-женски раздвинутым, приоткрытым верхом (так делают только молодые, неопытные солдаты - на солдатском жаргоне «чмыри» и «уёбки»). С другой стороны, здесь же приходит на ум пелотка в интернет-жаргоне как обозначение «девушки-пизды». Известно также выражение «сunt hair» 'пиздоволосая' (иногда более специфично для английских дам с веснушчатой кожей — «red cunt hair» 'пиздорыжеволосая', которое используется по меньшей мере с конца 1950-х годов, см. Lacombe 1994: 27). Существует выражение cunt-eyed ('пиздоглазый’), которое используется по отношению к человеку, имеющему некие странные проблемы со зрением. Семантическая параллель к этому - русское залупоглазый - человек у которого вместо глаз кругляшки полуслепой фаллической залуnы. Известно, что залупой обозначают оголенную (без крайней плоти) головку полового члена (glans penis), также известную как «залупень»; это отглагольные формы от залупить (по альтернативному мнению, матерная залуnа - это также сама по себе 'крайняя плоть'). Примечательно что «Залупа» - это также историческое прозвище русского князя и воеводы, друга Андрея Курбского - Ивана Петровича Охлябинина (вторая половина XVI века). См. биографическую заметку о нем: «Охлябинин, Иван Петрович, Князь Залупа». Русский биографический словарь: В 25 m. Т. 12: Обезьянинов - Очко. СПб., 1902. С. 476. В абсурдном узусе русского мата залупа имеет свое неотъемлемое присутствие: обсценное выражение «суп из конских залуn» есть ироничное замечание о чем-либо крайне несуразном и глупом. Известно также: «Химия, химия, вся залупа синяя»; или более натуралистичное: «Ясно, отчего залупа кра́сна». 
Характерно, что исходное существительное пизда получает новое значение от производного от нее глагола. О лексической (грамматически обусловленной) способности русского глагольного мата одновременно «значить много чего вообще» размышляли в свое время Дрейзин и Пристли. Согласно их выводам, матерный глагол может означать любое активное действие из некоего общего набора действий. Специфическое значение этот глагол приобретет в соответствии с этим общим набором и морфологической моделью, а также контекстуальным паттерном глагольных дополнений, лексическими единицами, выражающими эти дополнения, но также и в связи со всем контекстом высказывания ${ }^{46}$.

Глагол спи́здить означает 'украсть', что, кажется, более «логично», поскольку пизда воспринимается как пещера или (г)рот, то место, куда нечто входит или влагается и где можно что-то складировать втайне от посторонних глаз. Что тоже отчасти объяснимо схожестью пизды и уст, а в кошмарах - рта с зубами, как vagina dentata ${ }^{47}$, субъект и актор своего денотата, которая тоже может говорить, как в тексте известного рассказа Виктора Ерофеева «Персидская сирень» ${ }^{48}$.

Примечательно, что слово пиздатый означает нечто хорошее, тогда как слово хуёвый означает, напротив, нечто плохое. Притом идиоматически «nолучить пизды» (или «пиздюлей») означает пострадать в драке. А «получить хуй» означает почему-то не получить совсем ничего, в буквальном смысле пустотного «ничего» ничевоков. «Я получил хуй» (или «ни хуя не получил») означает 'я не получил ничего'49. Но наречия охуенно и пиздато (как и соответствующее прилагательные) при этом оказываются сущностными синонимами, как свидетельствует соответствующая поговорка: «Быть мужиком - охуенно, а быть женщиной — пиздато».

Недавно обнародована концертная записка, посланная Владимиру Маяковскому, - она свидетельствует о том, что в середине двадцатых годов уже активно использовалось прилагательное хуёвый в значении 'очень плохой'. Поэт хранил записки своих слушателей, большой корпус этих арте-

46 «...A mat verb may mean any intensive action from the total set of actions, and will acquire a specific meaning from this total set according to its morphological pattern and according to the contextual pattern of verbal complements, the lexical items occurring in these complements, and the whole context» (Dreizin, Priestly 1982: 241).

47 Vagina dentata («вагина с зубами»): о влагалищах с мощными членовредительными зубами имеется немало мифов в культуре индейских племен, а также в фантастических народных сказках Японии. В современной литературе этот мотив также присутствует в изобилии (например, у Берроуза или Пелевина).

48 В этом тексте, как известно, «Кант был посрамлен», поскольку не смог доподлинно прознать конечный смысл наличия или отсутствия бытия божьего; но также не вполне ясно, какой это был Кант - cunt ли (говорящий губами вагины), или все-таки философ Immanuel Kant.

49 В современном иврите имеется схожее грамматически отчасти абсурдное выражение, крайне часто употребляющееся, которое звучит «ло кибальти клум» или «ло клум», что дословно означает «я не получил [не] ничего», используемое в значении «полное ничего и ничто». Также часто обсценно говорится «кибальти зайн!» - в том же значении не получил ничего (= «получил хуй»). 
фактов был показан на московской выставке «Маяковский. Универсальный ответ записочникам $»^{50}$. «Почему вы пишите $<$ sic! $>$ такие хуёвые вещи как “Баня"? Возмутительно!» - написали Маяковскому возмущенные слушатели (см. фотографию: Александров 2018, а также репродукцию на с. 738 наст. изд.).

Когда фиксируется первое употребление антонима слова хуёвый прилагательного «пиздатый», пока не установлено, на эту тему необходимо собрать много лингво-корпусных свидетельств. Важнейший труд А. Плуцера-Сарно, первопроходческий в сфере лингвистики мата, посвященный подробному анализу исторической идиоматики гнездового слова «пизда», об этом, увы, умалчивает. О том, почему хуёвыц - это нечто очень плохое, а пиздатьй, наоборот, очень хорошее, можно лишь догадываться. Может быть, потому, что пизда - мягкое вместилище любого достойного объекта, может оставаться всегда позитивным объектом речи? Тогда как бессмысленный хуй, наоборот, будет жестким и эрегированным, ригидным и злым? Неужели в надзорно-народном сознании образ эрегирующего полового члена не соотносится с понятиями абсолютного добра и гуманистической радости?

Из классической работы М. И. Шапира (2015; впервые - в сборнике Анти-мир русской культуры, 1996) известно, что Маяковский с удовольствием работал с матерным субстратом. В частности, опубликована «Советская азбука», которую Маяковский составлял вместе с Романом Якобсоном в 1919 году. Шапир констатировал связь «Советской азбуки» с ее непечатными аналогами (связь, ранее прямо указанную самим Якобсоном, и завуалировано - самим Маяковским $)^{51}$. Вот примеры площадного порнографического претекста этой хрестоматийной авангардистской азбуки двустишия на буквы «А», «Ж» и «П»:

Арбуз на солнце любит греться,

Армяшка в жопу любит еться;

Жирафы в Африке пасутся,

Жиды по пятницам ебутся;

Пи-эр в квадрате - площадь круга,

Пизда утешит лучше друга. ${ }^{52}$

50 Выставка состоялась в «Галерее на Шаболовке» (23 апреля - 12 августа 2018 года), подробнее см. официальный сайт: https://www.nashabolovke-gallery.com/universalnyj-otvetzapisochnikam

51 Во время выступления в Доме комсомола Красной Пресни на вечере, посвященном двадцатилетию деятельности 25 марта 1930 г. Маяковский рассказывал: «Она была написана как пародия на старую, была такая порнографическая азбука. > ..> Она была написана для армейского употребления. Там были такие остроты, которые для салонов не очень годятся, но которые для окопов шли очень хорошо. $<\ldots .>$ Эту книгу $<\ldots>$ я принес печатать в Центропечать. Там сидела не вычищенная еще машинистка одна, которая с большой злобой мне сказала: “Лучше я потеряю всякую работу, но эту гадость я переписывать не буду”» (Маяковский 1959: 428-429).

52 Шапир 2015: 93, cp. 71. 
Сама по себе пизда оказывается источником многих абсурдных конструкций русской амбивалентной нарративной идиоматики. Одно из таких - примечательно-странное выражение «Иметь стеснение в пизде», где возникает апокрифическая сцена в (одесском?) борделе в начале двадцатого века, которую приводит словарь А. Плуцера-Сарно (2005: 92) - мадам хозяйка борделя обращается к клиенту:

- А вот как кстати, молоденькая девашечка, из французских, осьмнадцать годков, беленькая, нежненькая, персик настоящий, пизденочка узенькая - ну никак в самый раз для вас, открывать будете.

Помолчал купец, водки выпил еще, бороду погладил, и говорит:

- Видать по всему, никого-то я сегодня ебать и не буду.

- Дак что ж случилось, батюшка?!

- Да не пристало мне, купцу первой гильдии, поставщику Их Императорского Двора Еремею Феофановичу Почечуеву — в пизде стеснение иметь!

Здесь, как можно увидеть, обсценный абсурд нарастает в сторону некоторой смысловой деструкции в аспекте общей прагматики. Узкий орган никак не может считаться чем-то нежелательным, ибо в своей девственной нетронутой природной узкости несет очевидную половую ценность, в том числе и коммерческую (которую презревает персонаж-«купец»). Деструктивный подход к подобного рода практическому узусу характерен и для некоторых других текстов, связанных с этой идиоматикой. Например, в песне одного из рок-кумиров: «...Партизан спалил в пизду родную хату/ Завязался в узел ремешок!» 53 . Как можно что-либо «спалить в пизду», если воспринимать это выражение буквально? В данном случае двусмысленная экспрессивная идиома «в пизду» соотносится с другими дисфемизмами типа «в хлам» (в зюзю, в стельку, вдрызг, (не) в дугу, в жопу, в говно) то есть, исходно, вдребезги.

Идти в пизду связано также с глаголом пиздовать и его императивом пиздуй (в значении 'быстро, немедля иди прочь, иди <к черту!>'). Семантический диссонанс между пизде́mь и пиздова́ть привносит в дискуссию русское экспрессивное существительное пиздюк (отчасти синонимичное с «пиздуном»). Пиздюк несомненно связано с «говнюк» ${ }^{4}$, а также связано с целым рядом пейоративных форм на -юк, в том числе байстрюк и мандюк (от манда 'vulva': пизда//пиздюк ↔манда//мандюк). Ключ к разгадке и историческим глубинам здесь может являться интересное (уже литературное!) слово фетюк (Добродомов 1995а). Гоголь в Мертвых душах замечает, что слово фетюк многими почитается неприличным, поскольку якобы напоминает букву $\Theta$ и то, на что она похожа («...Өетюкъ слово обидное для

53 Из песни Егора Летова «Свобода 99» (цит. по: Плуцер-Сарно 2005: 156).

54 Стоит указать, что -yк/-юк - довольно редкий суффикс; см., например, бирюк или каюк, в которых морфемная структура неясна. Ср. также с «хуяк», или, наоборот «пиздык» — эксламационными инвективными формы без четкого семантического наполнения (о последнем феномене см., в частности, Plähn 1987). 
мужчины, происходитъ отъ $\Theta$, буквы, почитаемой нъкоторыми неприличною»). За старым «өетюк», возможно, уже стоит «пиздюк» - поскольку буква $\Theta$ (фита) неприлично похожа на пизду, подобно тому как (яркая типологическая параллель) ивритская буква т (зайн) похожа на хуй, отчего в современном иврите так и обозначается половой член. При этом гоголевская «этимология» — явно «народная» (Volksetymologie), ибо это слово, как и синонимичное ему фатюй, по всей видимости, следует возводить к венгерскому fattyú (мн. ч. fattyúk) 'внебрачный ребенок, выблядок, ублюдок' (Добродомов 1995a; 1995b: 264). Возможно, кстати, что тюфяк - это эвфемистическая анаграмма к неприличному слову фетюк.

4.

Важным этапом и примечательной научной вехой в изучении парадоксальной семантики русского мата стала статья Александра Жолковского «Секс в рамках», впервые опубликованная в журнале Новое литературное обозрение (Жолковский 1994) ${ }^{55}$. Она посвящена детальному структуралистскому анализу абсурдной и амбивалентной матерной поговорки «Нам, татарам, все равно, что ебать подтаскивать, что ёбаных оттаскивать». Когнитивный вопрос здесь вызывает изначальная темная двусмысленность - почему «ебать подтаскивать» равно «ёбаных оттаскивать»? Это два принципиально разных действия, требующих принципиально разной активности и умственной интенции. Эти два действия в своем пределе соотносятся как (самому́ активно кого-то) «ебать» versus пассивно и страдательно «быть кем-либо ебимымм». Это два принципиально разно-нагруженных действия, которые невозможно уравнять в плане отношении к ним. «Ебать подтаскивать» и «ёбаных оттаскивать» семантически коррелируют с такими поговорками, как «что в лоб что по лбу» (с инвариантным значением 'да и какая, собственно, разница?'), хотя смысл этих действий принципиально и сущностно иной.

Связанные с этим матерные двусмысленности как бы культивируются в самой знаковой структуре русской экспрессивной идиоматики. Один из примеров - обсценная дефиниция необсценного термина «нюанс» в известном матерном анекдоте.

Посланный учиться в Академию Генштаба Петька (концептуализированный Пелевиным как «Петр Пустота») возвращается к Чапаеву с жалобой на то, что он не понимает многих слов на занятиях. Одно из них - сложный термин «нюанс». Василий Иванович кряхтя признает, что на словах объяснить значение термина «нюанс» он не в силах, но «зато может показать» что это такое. Далее Василий Иваныч просит Петра снять штаны и стать раком. Петька снимает и становится. Василий Иваныч достает хуй и резко сует Петьке в жопу. Далее Чапаев уже вербально вслух поясняет смысл происходящего: «Вот смотри Петька - у тебя хуй в жопе! ...и у меня хуй в жопе. Но есть нюанс!..»

55 См. ее автокомментированную републикацию в нашем блоке. 
Работая в поле сходной идиоматики, Жолковский говорит о пронизывающей весь текст анализируемого им высказывания абсурдной установке на «неглагольность» «неопределенности и отчужденности». Согласно Жолковскому, «всё равно» - это безличное предикативное прилагательное, принадлежащее к так называемой категории состояния, грамматико-семантически противопоставленное личным формам глагола. Субъект при категории состояния выступает не в роли подлежащего, а в косвенном (дательном) падеже. Управляя инфинитивами, один из которых, в свою очередь, тоже вводит инфинитив, оборот «всё равно» открывает серию концентрических обрамлений — хиазмов.

Известны и другие присловья, сходные с изучавшимся Жолковским (некоторые из них он приводит в своей статье): «Mbl, татары, такие!» (не такие, как русские, например); «Нам, татарам, всё равно, что повидло, что говно»; «Нам, татарам, одна хуй: что война, что сабантуй»; «Нам, татарам, что водка, что пулемет - лишь бы с ног валило»; «Нам, татарам, всё равно - что бежать-наступать, что бежать-отступать» (всё равно бежать); «Нам, татарам, всё до фени» = «Нам, татарам, параллельно» $=\langle$ Нам, татарам, адекватно $\rangle=\langle Н а м$, татарам, конгруэнтно $\rangle ;$ «Нам, татарам, лишь бы даром»; «Нам, татарам, всё задаром»56.

Работа Жолковского стала одним из важных этапов в структурном изучении многих сходных экспонатов двусмысленной абсурдности русского матерного универсума. Подмеченный им абсурдный пласт поговоркиприсловья может быть рассмотрен на примерах некоторых однотипных выражений, культивирующих двусмысленность речевой дее-прагматики русского стёба. Укажем, например, такие 57 :

- Меня один подъябывал, а я его поябывал! (Непонятна линейно-деятельная связь подъёбки (издевательства) и собственно копуляции).

- На хуя мне без хуя, коль с хуями до хуя? (Загадочно-дзенская мудрость, перекликающаяся с джигурдинским «всем давно понять пора, на земле ликуя: нету хуя без добра и добра без хуя»).

- Нет хуя шире пизды. (Непонятно о какой ширине фаллоса по сравнению с вагиной вообще может идти речь).

- A вы, друзья, как ни садитесь, но только в жопу не ебитесь! (Непонятно чего ожидается от группы друзей, что им необходимо собственно делать).

- А какие это шутки - с босым хуем около голой пизды?! (Как член может быть бос и какие шутки могли бы возникнуть рядом с ним).

- Без огня дымм, да и хуй с ним! Без пиздюлей, как без пряников! (Непонятно почему без ударов-пиздюлей - это как без сладких пряников).

56 Ср. отдаленные смысловые корреляты этих формул: «Не ебут - не подмахивай»; «хуем груши околачивать»; «хуи валять и к стенке приставлять».

57 Нижеследующее взято из сетевых анонимных источников, «сетевого фольклора». На эту тему см. также: Kauffman 1980; Косцинский 1980. 
- Безрукий клеть обокрал, голопузому за пазуху наклал: слепой подглядывал, глухой подслушивал, немой караул закричал, а безногий нахуй пошел. (Описание тотального сюрреалистического абсурда, не поддающегося обычному пониманию).

- В пиздах - всяки ароматы, бриты есть и есть лохматыл. (Корреляции запахов и побритости неочевидны, хотя и не невозможны).

- Бляха-муха, и тебе хуй в ухо! (Помимо извечной неясности привлечения сюда «мухи» ${ }^{88}$ также неясно о чем здесь вообще может конкретно идти речь).

- Два хуя сметаны да на палец творогу, - чего бы продать? (Как могут быть два хуя сметаны?)

- В пизде на верхней полке, где ебутся волки! (Какая может быть там полка и главное, почему там волки).

- Ёбаный толченый пеликан! Заткни пизду, и не греми костями! (Как пеликан может быть еще и толчен? Вторая часть формулы также не оказывается чем-то простым и внятным).

- Захуй нам бросаться на хуй, если можно подождать?! (Странная игра слов без конкретного прагматического смысла, - но кажется с универсальной квази-дзенской интенцией неделания).

- Пиздюлина от часов. (Какое отношение часы имеют к вагине, неясно).

- Пошел нахуй! - Кусай захуй! Коли черная дыра, так дворянин. (В чем смысл укуса захуй и как связана черная дыра с дворянином?).

- Где была правда - там хуй вырос. (Как связан хуй с правдой, непонятно; и неужели хуй - растение?).

- Коль в пизде у бабы склизко, она уже не феминистка. (Смысл выражения в плане идиоматики и прагматики отнюдь не полностью прозрачен; паремия явно недавняя).

- Короче хуй - длиннее руки. Кости грызть - не хуй сосать.59 (Связь грызения костей и fellatio также не вполне ясна и понятна, как и их контрастирование).

- Ладушки, ладушки, вырос хуйу бабушки! (Как и почему может у бабушки вырасти мужской орган? И причем тут «ладушки» - знак согласия? мифо-аспект мы здесь выносим за скобки).

58 Бляха-муха - выражение крайнего удивления, досады-раздражения или иной сильной эмоции. Сходно с междометиями и восклицаниями, в том числе с другими эвфемизмами восклицания «блядь!» - такими, как блин, блин блинский; с эвфемизмами восклицания «ёб...» и «ёбаный...» (с любым продолжением) — такими, как ёлки-палки, ёшкин кот, ёкарный бабай, японский городовой; а также с фразеологией «чёрта»: чёрт возьми/побери и т. д.

59 Важно артикулировать семантическое отличие выражения в раздельно пишущихся словах «не хуй... (не палец, не залупу)» (сопрягаемого с глаголами: слюнявить, сосать, дрочить, ебать, держать, мочить, лизать, колупать, залупать, отряхивать, теребить или оттягивать); и слитно пишущегося наречия «нехуй» В значении «не надо», «нельзя», «лучше бы не», «запрещено», или в выражении «нехуй делать» - «легко и просто», «как два пальца обоссать». 
- Лишний хуй в жопе не помеха или Лучше синица в руке, чем хуй в жопе. (Примеры псевдозагадочных обсценных речений, представляющих собой контаминацию матерной идиомы с гораздо более благопристойными паремиями) ${ }^{60}$.

Можно привести и многие другие подобные отчасти абсурдные когнитивно-диссонансные выражения.

Русский мат подчас принимает крипто-черты полноценного «ботания по фене», создавая свой собственный особый кодовый семио-язык экстремальной обсценной многозначности. Каждое «человеческое» действие как будто обретает свой «параллельный» половой к(л)инический эквивалент, сохраняющий между тем денотат реальности, в интенции подлежащий четкому семиотическому расшифровыванию. Дрейзин и Пристли иллюстрируют (и вновь демонстрируют) этот уникальный языковой феномен русского мата на примере краткой характерной «национальной» сценки в советском едущем автобусе, педантично приводя матерный, «нормальный» и «переводной» речевые варианты (Dreizin, Priestly 1982: 247):

Xujáčitsja èta pizdóvina - vot-vot naebnëtsja: vsjákoj pizdorváni nevproëb. I vot odin nedoệbok (ebálo na odnóm sikele xeráčitsja) vpizživaetsja kak pizdanittyj, až vsé oxuéli. Prö̈bsja skvoz' vsju xuebrátiju i pizdyk! - vxujáčilsja v edinstvennoe prožóp'e: vy, mol, stárye próbljadi, pizdújte vstoják, poká vam pizda ne prixujáčit.

Non-mat version:

Idët ètot avtóbus - čut' ne pádaet, tak mnógo passažírov. I vot odín molodój čelovék (golová éle déržitsja bog znáet na čëm) vtískivaetsja, kak sumasšédšij, vsé až rot razinúli. Protísnulsja skvoz' passažírov i xlóp! zánjal edínstvennoe svobódnoe mésto: vy, mol, starúxi, ezžájte stója, poká vam konéc ne pridët.

English translation:

The bus was going along, and almost falling over, there were so many passengers. And then one young man (his head held up on God knows what) pushed his way on, like a madman, so that everyone gaped. He pushed through the passengers and with a thump took the only vacant seat, as much as to say: you, old women, can travel standing up till your end comes (till you're finished).

О сходных с этим компаративных моментах многозначности русского мата говорят различные словари, исследования и антологии ${ }^{61}$. Подлинным кладезем абсурдного мата и стёбной полисемии являются многие тексты песен Сергея Шнурова, лидера группировки «Ленинград».

60 Такого рода паремиологические контаминации любил Маяковский: «Не плюй в колодец — вылетит, не поймаешь» (Квятковский 1966: 138; Февральский 1971: 49). Возможно, среди них были и матерные.

61 См. Буй 2005 (первая публикация - 1995); Манаков 1997; Волков 1999; Жельвис 2001; и др. 
Укажем на один из наиболее примечательных в этом плане текстов; его название также абсурдно и никак не связано с содержанием или с визуальным рядом видеоклипа - эта песня почему-то называется «Скоро в школу» (2014):

Ноги как утюги, / кругом одни враги.

Ты меня послала нахуй,/на пальто надев рубаху!

Нахуй не иду, а иду в пизду. /Нахуй не иду, а иду в пизду.

Руки как клешни краба - /штырит меня не слабо.

Как в кино про Росомаху -/ты меня послала нахуй.

Но... Нахуй не иду, а иду в пизду./Нахуй не иду, а иду в пизду.

Белый как порошок, —/водка на портвешок.

И нет любви и нет страха, / ты меня послала нахуй.

Нахуй не иду, а иду в пизду...62

Важно указать что нахуй здесь грамматически оказывается наречием, как «домой», «назад», или в одесском варианте «тудой-сюдой» и т. д. «Пойти в пизду», как пойти в народ, означает отчасти сгинуть, раствориться в вязкой материи гибельно-засасывающего пахучего и мохнатого болота (или легендарной приговской «махроти»). В плане слитного правописания этот вопрос в свое время апокрифически исчерпал ведущий советский грамматист Д. Э. Розенталь. По легенде, однажды любознательный советский студент спросил у Дитмара Эльяшевича Розенталя «Скажите пожалуйста, как пишется русское выражение "похуй" - слитно или раздельно?» На что он получил ответ: «Если это характеристика моего отношения к Вам, молодой человек, - невозмутимо ответил Розенталь, — то слитно. А если обозначение глубины великой еврейской реки Иордан, то раздельно». Великому лингвисту И. А. Бодуэну-де-Куртенэ наречие «похуй» еще не было известно, но наречие «на-хуй» он писал через дефис (см. с. 737 наст. изд.).

В контексте же песни группировки «Ленинград» важно понять, чем семантически отличается поход на хуй (на-хуй, нахуй) от похода в пизду, крайне трудно, и, видимо, в этом и состоит идиостилистический провокативно-амбивалентный мессидж Сергея Шнурова. Возможный мессидж здесь, вероятно, состоит в том, чтобы остановиться на краткий миг и задуматься о царящем вокруг когнитивном диссонансе. Возможно также, разница заключается в том, что не важно куда, но важно как. «Пойти в пизду», оказывается, почему-то лучше, чем идти «нахуй».

Укажем в данной связи, что в XIX веке в России посылали не на хуй, но к хую или к херу — как к некоему субъекту запредельного, недостижимого, инфернально-обсценного адреса, дальше чем $к$ чёрту ${ }^{63}$. В этом контексте «на хуй не иду, но иду в пизду» может означать как бесцельную, закольцо-

62 См. видеоклип: https://www.youtube.com/watch?v=Va1UpS0Eiag.

63 Не является ли это выражение заклинательным рудиментом древнеславянского (фаллическо-языческого) культа? Эва Кёлз в своей знаменитой монографии обозначила это явление на материале классической античности как The Reign of the Phallus - Царствие Большого Фаллоса (Keuls 1993). 
ванную коаном похуистического стёба ходьбу на месте, так и ритуальную формулу нежелания следовать пагубной тропой. Главное действующее лицо видеоклипа - начинающий горе-коммивояжер, который, в частности, пытается продать фаллоимитаторы. В один момент он чуть не становится жертвой гея, который, пропустив его в квартиру, вкрадчивым жестом предлагает ему сесть «рядом» - т. е. по сути, «и рыбку съесть» (продав свой товар и получив прибыль) «и на хуй сесть», что главный герой с негодованием отвергает, ибо «на хуй не иду!» В таком герменевтическом ракурсе припев-рефрен клипа должен указывать на горделивое утверждение гетеросексуальной природы героя. При этом едва ли не самый очевидный семантический пласт поверхности клипа вероятно состоит в передаче сообщения о том, что некая скрытая от наших глаз девушка отставила главного героя. Что ж, подумал он, — «иду к другой».

Дополнительной возможной интерпретацией этого криптографического нарратива может быть самурайское предпочтение более приемлемого способа заведомо неизбежной и неминуемой гибели всерьез. Подбирая в этом смысловом прагма-контексте русский народный эквивалент, можно подумать о выражении «помирать - так с музыкой». В данном случае, в России здесь и сейчас, — с музыкой группировки «Ленинград».

\section{ЛИТЕРАТУРА}

Аввакум. Житие протопопа Аввакума им самим написанное и другие его сочинения. Под ред. Н. К. Гудзия. М.: Гос. изд-во художественной литературы, 1960.

Августин. «О христианском учении» [фрагменты]. Пер. С. Неретиной. Антология средневековой мысли в 2 томах. Т. 1. СПб.: РХГИ, 2001: 66-112.

Александров Д. «В музее показали записки, которые передавали из зала Маяковскому. Комменты были такими злыми и 100 лет назад». Medialeaks, 24.04.2018. https:// medialeaks.ru/2404dalex-yt-srach-v-kamentah/

Андреева Екатерина. Угол несоответствия. Школь нонконформизма: Москва - Ленинград, 1946-1991. М.: Искусство - ХХІ век, 2012.

Барков И. и др. Девичья игрушка, или Сочинения господина Баркова. Изд. подгот. А. Зорин и Н. Сапов [С. И. Панов]. М.: Ладомир, 1992.

Буй Василий. Русская заветная идиоматика: Веселый словарь народных выражений. Ред.: д. ф. н., проф. А. Н. Баранов и д. ф. н., проф. Д. О. Добровольский. Изд. 2-е, испр. и доп. М.: Альта-Принт, 2005.

Волков А. Д. Заветные частушки из собрания А. Д. Волкова. Изд. подгот. А. В. Кулагина. Т. 1-2. М.: Ладомир, 1999.

Гаспаров М. Л. «Амфиболия». Литературная энциклопедия терминов и понятий. Гл. ред. и сост. ред. А. Н. Николюкин. М.: Интелвак, 2001: 30.

Гура А. В. Символика животных в славянской народной традиции. М.: Индрик, 1997.

Добродомов И. Г. «Ноздревское слово фетюк». Русский язык в школе 3 (1995a): 75-78.

Добродомов И. Г. «Венгерское ругательство в эпистолярии Батюшкова». Philologica 2 (1995b): 263-265.

Довлатов С. Собрание сочинений. Т. 2. СПб.: Азбука, 1999.

Жельвис В. И. Поле брани: Сквернословие как соииальная проблема. Изд. 2-е, перераб. и доп. М.: Ладомир, 2001.

Живов В. М. Язык и культура в России XVIII века. М.: Школа «Языки русской культуры», 1996.

Жолковский А. К. «Секс в рамках (“Нам, татарам, все равно...”)». Новое литературное обозрение 6 (1994): 15-24. 
Зализняк А. А. «Поправки и замечания к чтению ранее опубликованных берестяных грамот». В. Л. Янин, А. А. Зализняк. Новгородские грамоты на бересте. Т. 10: (из раскопок 1990-1996 г2.). М.: Русские словари, 2000: 82-122.

Зализняк А. А., Янин В. Л. «Берестяные грамоты из новгородских раскопок 2005 г.». Bопросы языкознания 3 (2006): 3-13.

Иоффе Д. Г. (ред.). Дискурсы телесности и эротизма в литературе и культуре: Эпоха модернизма. Сборник научных статей под ред. Д. Г. Иоффе. М.: Ладомир, 2008.

Иоффе Д. Г. «Велимир Хлебников, ЧК и амфиболический дискурс. К вопросу риториколингвистической критики поэтического текста». Критика и семиотика 10 (2006): $113-141$.

Иоффе Д. Г. «К вопросу о радикальной эстетике Второго русского авангарда». Новое литературное обозрение 140 (2016): 287-314.

Квятковский А. П. Поэтический словарь. М.: Советская энциклопедия, 1966.

Косцинский К. «Ненормативная лексика и словари (К постановке вопроса)». Russian Linguistics 4.4 (1980): 383-396.

Куприн А. Звезда Соломона. Гельсингфорс: Библион, 1920.

Левин Ю. И. «Об обсценных выражениях русского языка». Russian Linguistics 10.1 (1986): $61-72$.

Лосев А. Ф. «Ирония античная и романтическая». Эстетика и искусство. Из истории домарксистской эстетической мысли. Сост. и ред. П. С. Трофимов. М.: Наука, 1966: $54-84$.

Лосев А. Ф., Шестаков В. П. История эстетических категорий. М.: Искусство, 1965.

Малышев В. И. «Два неизвестных письма протопопа Аввакума». Tpуды Oтдела древнерусской литературы 14 (1958): 413-420.

Манаков А. Блуд на Руси: Свидетельские показания и литературные версии. М.: Колокол-пресс, 1997.

Маяковский В. В. Полное собрание сочинений: В 13 томах. Т. 12. М.: Художественная литература, 1959.

Мокиенко В. М. «Русская бранная лексика: Цензурное и нецензурное». Rusistik/Pycuстика 11/12 (1994): 50-73.

Назаров В. Д. «“Срамословие” в топонимике России XV-XVI вв.» «A се грехи злье, смертные...»: Любовь, эротика и сексуальная этика в доиндустриальной России (X-nервая половина ХІХ в.). Ред. Н. Л. Пушкарева. М.: Ладомир, 1999: 551-563.

Плуцер-Сарно А. Ю. Большой словарь мата. Т. 2: Опьт построения справочно-библиографической базы данных лексических и фразеологических значений слова «пизда». СПб.; М.: Лимбус Пресс, 2005.

Попов Алексей. Православные русские акафисты, изданные с благословения Святейтего Синода: История их происхождения и иензуры, особенности содержания и построения. Казань: Типо-литография Имп. Казанского университета, 1903.

Ранкур-Лаферьер Д. «К постановке проблемы семиотики пениса». Дискурсы телесности и эротизма в литературе и культуре: Эпоха модернизма. Сборник научных статей под ред. Д. Г. Иоффе. М.: Ладомир, 2008: 53-114.

Рождественский Р. В. «К истории борьбы с церковными беспорядками, отголосками язычества и пороками в русском быту XVII в.» Чтения в Обществе истории и древностей российских при Императорском Московском университете 2 (1902): 30-37.

Романов Б. А. Люди и нравы Древней Руси. Историко-бытовые очерки XI-XIII веков. М.; Л.: Наука, 1966.

Россомахин А., Замятина О. «Как сделана "Машина” Шнурова (К дешифровке эсхатологического восторга)». Зборник Майице срйске за славистиику 98 (2020): 128-143.

Соловьев В. С. «Жизненная драма Платона». В. С. Соловьев. Сочинения в 2 mомах. Т. 2 (Философское наследие 105). М.: Мысль, 1988: 582-625.

Топорков А. Л. Русский эротический фольклор. Сост. и науч. ред. А. Л. Топорков. М.: Ладомир, 1995.

Успенский Б. А. «Мифологический аспект русской экспрессивной фразеологии». Б. А. Успенский. Избранные трудыл. Т. 2: Язык и культура. М.: Гнозис, 1994: 53-128.

Февральский А. В. Встречи с Маяковским. М.: Советская Россия, 1971. 
Филарет. Собрание мнений и отзывов Филарета, митрополита московского и коломенского, по учебным и иерковно-государственным вопросам. Т. 4. М.: В Синодальной типографии, 1886.

Шапир М. И. «К семантике “пародического балладного стиха” (“Солнце” Маяковского в тени Баркова)». М. И. Шапир. Universum versus: Язык-cтих-смысл в русской поэзии XVIII-XX веков. Кн. 2. М.: Языки славянской культуры, 2015: 62-99.

ЭССЯ = Этимологический словарь славянских языков: Праславянский лексический фонд. Под ред. чл.-корр. АН СССР О. Н. Трубачева. М.: Наука, 1975. Вып. 2; 1977. Вып. 4; 1979. Вып. 6.

Юрганов А. Л. «Из истории табуированной лексики: Что такое “блядь” и кто такой “блядин сын” в культуре русского средневековья». Одиссей. Человек в истории. М.: Наука, 2000: 194-206.

Янин В. Л., Зализняк А. А., Гиппиус А. А. Новгородские грамоты на бересте. Т. 11: (из раскопок 1997-2000 г2.). М.: Русские словари, 2004.

Baker N., Holt R. "Towards a Geography of Sexual Encounter: Prostitution in English Medieval Towns", Indecent Exposure: Sexuality, Society and the Archaeological Record. Ed. by Lynne Bevan. Glasgow: Cruithne Press, 2001: 187-198.

Borowsky Ron, Masson Michael E. J. "Semantic Ambiguity Effects in Word Identification". Journal of Experimental Psychology: Learning, Memory, and Cognition 22 (1996): 63-85.

Chantraine, Pierre. Dictionnaire étymologique de la langue grecque. Histoire des mots. Vol. 1. Paris: Klincksieck, 1968.

Cuyckens Hubert, Sandra Dominiek, Rice Sally. "Towards an empirical lexical semantics". Human Contact through Language and Linguistics. Eds. S. Birgit, T. Mieke. Frankfurt am Main [etc.]: Peter Lang, 1997: 35-54.

Dreizin Felix, Priestly Tom. "A Systematic Approach to Russian Obscene Language". Russian Linguistics 6.2 (1982): 233-249.

Elleström Lars. Divine Madness: On Interpreting Literature, Music, and Visual Arts Ironically. Lewisburg: Bucknell University Press, 2002.

Falconer William. An Universal Dictionary of the Marine; or, A copious explanation of the technical terms and phrases employed in the construction, equipment, furniture, machinery, movements, and military operations of a ship. London: T. Cadell, 1780.

Gibbs Raymond W., Matlock Teenie. "Psycholinguistic Perspectives on Polysemy". Polysemy in Cognitive Linguistics: Selected papers from the International Cognitive Linguistics Conference, Amsterdam, 1997. Ed. by Hubert Cuyckens and Britta E. Zawada. (Current Issues in Linguistic Theory 177). Amsterdam; Philadelphia: John Benhjamins, 2001: 213-239.

Grillo R. D. Dominant Languages: Language and Hierarchy in Britain and France. Cambridge: Cambridge University Press, 1989.

Grose Francis. A Classical Dictionary of the Vulgar Tongue. 2nd ed. London: S. Hooper, 1788.

Harrer G. A. "Saul Who Also Is Called Paul". The Harvard Theological Review 33.1 (1940): $19-33$.

Hino Yasushi, Pexman Penny M., Lupker Stephen J. "Ambiguity and Relatedness Effects in Semantic Tasks: Are they Due to Semantic Coding?". Journal of Memory and Language 55.2 (2006): 247-273.

Ioffe Dennis. "Review of: Henrietta Mondry. Political Animals: Representing Dogs in Modern Russian Culture. Amsterdam: Brill — Rodopi, 2015". Australian Slavonic and East European Studies 30.1-2 (2016): 189-194.

Jastrzembski James E. "Multiple Meanings, Number of Related Meanings, Frequency of Occurrence, and the Lexicon". Cognitive Psychology 13.2 (1981): 278-305.

Kauffman Charles A. "A Survey of Russian Obscenities and Invective Usage". Maledicta 4.2 (1980): 261-289.

Keuls Eva C. The Reign of the Phallus: Sexual Politics in Ancient Athens. Berkeley, CA: University of California Press, 1993.

Kleiber Georges. Problèmes de sémantique: la polysémie en questions. Villeneuve d'Ascq: Presses Universitaires du Septentrion, 1999.

Klein Devorah E., Murphy Gregory L. "The Representation of Polysemous Words". Journal of Memory and Language 45.2 (2001): 259-282. 
Klepousniotou Ekaterini, Baum Shari R. "Disambiguating the Ambiguity Advantage Effect in Word Recognition: An advantage for Polysemous but not Homonymous Words". Journal of Neurolinguistics 20.1 (2007): 1-24.

Kroonen Guus. Etymological Dictionary of Proto-Germanic. (Leiden Indo-European Etymological Dictionary 11). Leiden: Brill, 2013.

Lacombe Dany. Blue Politics: Pornography and the Law in the Age of Feminism. Toronto: University of Toronto Press, 1994.

Leary T. J. "Paul's Improper Name". New Testament Studies 38 (1992): 467-469.

Nunberg Geoffrey. "Transfers of Meaning”. Journal of Semantics 12.2 (1995): 109-132.

$O E D=$ The Oxford English Dictionary. 2nd ed. Vol. 4. Oxford: Clarendon Press, 1989.

Plähn Jürgen. «Хуйня-муйня и тому подобное». Russian Linguistics 11.1 (1987): 37-41.

Ravin Yael, Leacock Claudia (eds.). Polysemy: Theoretical and Computational Approaches. Oxford: Oxford University Press, 2000.

Rees Emma L. E. The Vagina: A Literary and Cultural History. New York, London [etc.], 2013.

Rodd Jennifer, Gaskell Gareth, Marslen-Wilson William. "Making Sense of Semantic Ambiguity: Semantic Competition in Lexical Access". Journal of Memory and Language 46.2 (2002): $245-266$.

Tsunoda T. "Transitivity". The Encyclopedia of Language and Linguistics. Eds. R. E. Asher, J. M. Y. Simpson. Vol. 9. Oxford; New York: Pergamon Press, 1994: 4670-4677.

Verspoor Marjolijn, Lowies Wander. "Making Sense of Polysemous Words”. Language Learning 53.3 (2003): 547-586.

\section{LITERATURE}

Aleksandrov D. "V muzee pokazali zapiski, kotorye peredavali iz zala Maiakovskomu. Kommenty byli takimi zlymi i 100 let nazad”. Medialeaks, 24.04.2018. https://medialeaks.ru/2404dalexyt-srach-v-kamentah/

Andreeva Ekaterina. Ugol nesootvetstviia. Shkoly nonkonformizma: Moskva - Leningrad, 19461991. M.: Iskusstvo - XXI vek, 2012.

Augustinus. "O khristianskom uchenii" [fragmenty]. Per. S. Neretinoi. Antologiia srednevekovoi mysli $v 2$ tomakh. T. 1. SPb.: RKhGI, 2001: 66-112.

Avvakum. Zhitie protopopa Avvakuma im samim napisannoe i drugie ego sochineniia. Pod red. N. K. Gudziia. M.: Gos. izd-vo khudozhestvennoi literatury, 1960.

Baker N., Holt R. "Towards a Geography of Sexual Encounter: Prostitution in English Medieval Towns", Indecent Exposure: Sexuality, Society and the Archaeological Record. Ed. by Lynne Bevan. Glasgow: Cruithne Press, 2001: 187-198.

Barkov I. i dr. Devich'ia igrushka, ili Sochineniia gospodina Barkova. Izd. podgot. A. Zorin i N. Sapov [S. I. Panov]. M.: Ladomir, 1992.

Borowsky Ron, Masson Michael E. J. "Semantic Ambiguity Effects in Word Identification". Journal of Experimental Psychology: Learning, Memory, and Cognition 22 (1996): 63-85.

Bui Vasilii. Russkaia zavetnaia idiomatika: Veselyi slovar' narodnykh vyrazhenii. Red.: d. f. n., prof. A. N. Baranov i d. f. n., prof. D. O. Dobrovol'skii. Izd. 2-e, ispr. i dop. M.: Al'ta-Print, 2005.

Chantraine, Pierre. Dictionnaire étymologique de la langue grecque. Histoire des mots. Vol. 1. Paris: Klincksieck, 1968.

Cuyckens Hubert, Sandra Dominiek, Rice Sally. "Towards an empirical lexical semantics". Human Contact through Language and Linguistics. Eds. S. Birgit, T. Mieke. Frankfurt am Main [etc.]: Peter Lang, 1997: 35-54.

Dobrodomov I. G. "Nozdrevskoe slovo fetiuk". Russkii iazyk v shkole 3 (1995a): 75-78.

Dobrodomov I. G. "Vengerskoe rugatel'stvo v epistoliarii Batiushkova". Philologica 2 (1995b): 263-265.

Dovlatov S. Sobranie sochinenii. T. 2. SPb.: Azbuka, 1999.

Dreizin Felix, Priestly Tom. "A Systematic Approach to Russian Obscene Language". Russian Linguistics 6.2 (1982): 233-249.

Elleström Lars. Divine Madness: On Interpreting Literature, Music, and Visual Arts Ironically. Lewisburg: Bucknell University Press, 2002. 
ESSYa = Etimologicheskii slovar' slavianskikh yazykov: Praslavianskii leksicheskii fond. Pod red. chl.-korr. AN SSSR O. N. Trubacheva. M.: Nauka, 1975. Vyp. 2; 1977. Vyp. 4; 1979. Vyp. 6.

Falconer William. An Universal Dictionary of the Marine; or, A copious explanation of the technical terms and phrases employed in the construction, equipment, furniture, machinery, movements, and military operations of a ship. London: T. Cadell, 1780.

Fevral'skii A. V. Vstrechi s Maiakovskim. M.: Sovetskaia Rossiia, 1971.

Filaret. Sobranie mnenii i otzyvov Filareta, mitropolita moskovskogo i kolomenskogo, po uchebnym i tserkovno-gosudarstvennym voprosam. T. 4. M.: V Sinodal'noi tipografii, 1886.

Gasparov M. L. "Amfiboliia". Literaturnaia entsiklopediia terminov i poniatii. Gl. red. i sost. red. A. N. Nikoliukin. M.: Intelvak, 2001: 30.

Gibbs Raymond W., Matlock Teenie. "Psycholinguistic Perspectives on Polysemy". Polysemy in Cognitive Linguistics: Selected papers from the International Cognitive Linguistics Conference, Amsterdam, 1997. Ed. by Hubert Cuyckens and Britta E. Zawada. (Current Issues in Linguistic Theory 177). Amsterdam; Philadelphia: John Benhjamins, 2001: 213-239.

Grillo R. D. Dominant Languages: Language and Hierarchy in Britain and France. Cambridge: Cambridge University Press, 1989.

Grose Francis. A Classical Dictionary of the Vulgar Tongue. 2nd ed. London: S. Hooper, 1788.

Gura A. V. Simvolika zhivotnykh v slavianskoi narodnoi traditsii. M.: Indrik, 1997.

Harrer G. A. "Saul Who Also Is Called Paul". The Harvard Theological Review 33.1 (1940): $19-33$.

Hino Yasushi, Pexman Penny M., Lupker Stephen J. "Ambiguity and Relatedness Effects in Semantic Tasks: Are they Due to Semantic Coding?". Journal of Memory and Language 55.2 (2006): 247-273.

Ioffe D. G. (red.). Diskursy telesnosti i erotizma v literature i kul'ture: Epokha modernizma. Sbornik nauchnykh statei pod red. D. G. Ioffe. M.: Ladomir, 2008.

Ioffe D. G. "K voprosu o radikal'noi estetike Vtorogo russkogo avangarda". Novoe literaturnoe obozrenie 140 (2016): 287-314.

Ioffe D. G. "Velimir Khlebnikov, ChK i amfibolicheskii diskurs. K voprosu ritoriko-lingvisticheskoi kritiki poeticheskogo teksta". Kritika i semiotika 10 (2006): 113-141.

Ioffe Dennis. "Review of: Henrietta Mondry. Political Animals: Representing Dogs in Modern Russian Culture. Amsterdam: Brill — Rodopi, 2015". Australian Slavonic and East European Studies 30.1-2 (2016): 189-194.

Jastrzembski James E. "Multiple Meanings, Number of Related Meanings, Frequency of Occurrence, and the Lexicon". Cognitive Psychology 13.2 (1981): 278-305.

Kauffman Charles A. "A Survey of Russian Obscenities and Invective Usage". Maledicta 4.2 (1980): 261-289.

Keuls Eva C. The Reign of the Phallus: Sexual Politics in Ancient Athens. Berkeley, CA: University of California Press, 1993.

Kleiber Georges. Problèmes de sémantique: la polysémie en questions. Villeneuve d'Ascq: Presses Universitaires du Septentrion, 1999.

Klein Devorah E., Murphy Gregory L. "The Representation of Polysemous Words". Journal of Memory and Language 45.2 (2001): 259-282.

Klepousniotou Ekaterini, Baum Shari R. "Disambiguating the Ambiguity Advantage Effect in Word Recognition: An advantage for Polysemous but not Homonymous Words". Journal of Neurolinguistics 20.1 (2007): 1-24.

Kostsinskii K. "Nenormativnaia leksika i slovari (K postanovke voprosa)". Russian Linguistics 4.4 (1980): 383-396.

Kroonen Guus. Etymological Dictionary of Proto-Germanic. (Leiden Indo-European Etymological Dictionary 11). Leiden: Brill, 2013.

Kuprin A. Zvezda Solomona. Helsingfors: Biblion, 1920.

Kviatkovskii A. P. Poeticheskii slovar'. M.: Sovetskaia entsiklopediia, 1966.

Lacombe Dany. Blue Politics: Pornography and the Law in the Age of Feminism. Toronto: University of Toronto Press, 1994.

Leary T. J. "Paul's Improper Name”. New Testament Studies 38 (1992): 467-469.

Levin Yu. I. "Ob obstsennykh vyrazheniiakh russkogo yazyka". Russian Linguistics 10.1 (1986): $61-72$. 
Losev A. F. "Ironiia antichnaia i romanticheskaia". Estetika i iskusstvo. Iz istorii domarksistskoi esteticheskoi mysli. Sost. i red. P. S. Trofimov. M.: Nauka, 1966: 54-84.

Losev A. F., Shestakov V. P. Istoriia esteticheskikh kategorii. M.: Iskusstvo, 1965.

Maiakovskii V. V. Polnoe sobranie sochinenii: V 13 tomakh. T. 12. M.: Khudozhestvennaia literatura, 1959.

Malyshev V. I. "Dva neizvestnykh pis'ma protopopa Avvakuma”. Trudy Otdela drevnerusskoi literatury 14 (1958): 413-420.

Manakov A. Blud na Rusi: Svidetel'skie pokazaniia i literaturnye versii. M.: Kolokol-press, 1997.

Mokienko V. M. "Russkaia brannaia leksika: Tsenzurnoe i netsenzurnoe". Rusistik = Rusistika 11/12 (1994): 50-73.

Nazarov V. D. “'Sramoslovie' v toponimike Rossii XV-XVI vv. "A se grekhi zlye, smertnye...”: Liubov', erotika i seksual'naia etika $v$ doindustrial'noi Rossii $(X$ - pervaia polovina XIX v.). Red. N. L. Pushkareva. M.: Ladomir, 1999: 551-563.

Nunberg Geoffrey. "Transfers of Meaning”. Journal of Semantics 12.2 (1995): 109-132.

OED = The Oxford English Dictionary. 2nd ed. Vol. 4. Oxford: Clarendon Press, 1989.

Plähn Jürgen. "Khuinia-muinia i tomu podobnoe". Russian Linguistics 11.1 (1987): 37-41.

Plutser-Sarno A. Yu. Bol'shoi slovar' mata. T. 2: Opyt postroeniia spravochno-bibliograficheskoi bazy dannykh leksicheskikh i frazeologicheskikh znachenii slova «pizda». SPb.; M.: Limbus Press, 2005.

Popov Aleksei. Pravoslavnye russkie akafisty, izdannye s blagosloveniia Sviateishego Sinoda: Istoriia ikh proiskhozhdeniia i tsenzury, osobennosti soderzhaniia i postroeniia. Kazan: Tipo-litografiia Imp. Kazanskogo universiteta, 1903.

Rancour-Laferriere Daniel. "K postanovke problemy semiotiki penisa". Diskursy telesnosti i erotizma v literature i kul'ture: Epokha modernizma. Sbornik nauchnykh statei pod red. D. G. Ioffe. M.: Ladomir, 2008: 53-114.

Ravin Yael, Leacock Claudia (eds.). Polysemy: Theoretical and Computational Approaches. Oxford: Oxford University Press, 2000.

Rees Emma L. E. The Vagina: A Literary and Cultural History. New York, London [etc.], 2013.

Rodd Jennifer, Gaskell Gareth, Marslen-Wilson William. "Making Sense of Semantic Ambiguity: Semantic Competition in Lexical Access". Journal of Memory and Language 46.2 (2002): $245-266$.

Romanov B. A. Liudi i nravy Drevnei Rusi. Istoriko-bytovye ocherki XI-XIII vekov. M.; L.: Nauka, 1966.

Rossomakhin A., Zamiatina O. “Kak sdelana 'Mashina' Shnurova (K deshifrovke eskhatologicheskogo vostorga)". Matica Srpska Journal of Slavic Studies 98 (2020): 128-143.

Rozhdestvenskii R. V. "K istorii bor'by s tserkovnymi besporiadkami, otgoloskami yazychestva i porokami v russkom bytu XVII v." Chteniia v Obshchestve istorii i drevnostei rossiiskikh pri Imperatorskom Moskovskom universitete 2 (1902): 30-37.

Shapir M. I. "K semantike 'parodicheskogo balladnogo stikha' ('Solntse' Maiakovskogo v teni Barkova)". M. I. Shapir. Universum versus: Yazyk - stikh - smysl v russkoi poezii XVIIIXX vekov. Kn. 2. M.: Yazyki slavianskoi kul'tury, 2015: 62-99.

Solov'ev V. S. "Zhiznennaia drama Platona”. V. S. Solov'ev. Sochineniia v 2 tomakh. T. 2 (Filosofskoe nasledie 105). M.: Mysl', 1988: 582-625.

Toporkov A. L. Russkii eroticheskii fol'klor. Sost. i nauch. red. A. L. Toporkov. M.: Ladomir, 1995.

Tsunoda T. "Transitivity". The Encyclopedia of Language and Linguistics. Eds. R. E. Asher, J. M. Y. Simpson. Vol. 9. Oxford; New York: Pergamon Press, 1994: 4670-4677.

Uspenskii B. A. "Mifologicheskii aspekt russkoi ekspressivnoi frazeologii". B. A. Uspenskii. Izbrannye trudy. T. 2: Yazyk i kul'tura. M.: Gnozis, 1994: 53-128.

Verspoor Marjolijn, Lowies Wander. "Making Sense of Polysemous Words". Language Learning 53.3 (2003): 547-586.

Volkov A. D. Zavetnye chastushki iz sobraniia A. D. Volkova. Izd. podgot. A. V. Kulagina. T. 1-2. M.: Ladomir, 1999.

Yanin V. L., Zalizniak A. A., Gippius A. A. Novgorodskie gramoty na bereste. T. 11: (iz raskopok 1997-2000 gg.). M.: Russkie slovari, 2004.

Yurganov A. L. "Iz istorii tabuirovannoi leksiki: Chto takoe 'bliad" i kto takoi 'bliadin syn' v kul'ture russkogo srednevekov'ia". Odissei. Chelovek v istorii. M.: Nauka, 2000: 194-206. 
Zalizniak A. A. "Popravki i zamechaniia k chteniiu ranee opublikovannykh berestianykh gramot". Yanin V. L., Zalizniak A. A. Novgorodskie gramoty na bereste. T. 10: (iz raskopok 19901996 gg.). M.: Russkie slovari, 2000: 82-122.

Zalizniak A. A., Yanin V. L. "Berestianye gramoty iz novgorodskikh raskopok 2005 g." Voprosy yazykoznaniia 3 (2006): 3-13.

Zhel'vis V. I. Pole brani: Skvernoslovie kak sotsial'naia problema. Izd. 2-e, pererab. i dop. M.: Ladomir, 2001.

Zhivov V. M. Yazyk i kul'tura v Rossii XVIII veka. M.: Shkola "Yazyki russkoi kul'tury", 1996.

Zholkovsky A. K. "Seks v ramkakh ('Nam, tataram, vse ravno...')". Novoe literaturnoe obozrenie 6 (1994): 15-24.

Денис Иофе

ПОВОДОМ ПЕРФОРМАТИВНЕ ВИШЕЗНАЧНОСТИ РУСКИХ ПСОВКИ

Резиме

У чланку се разматрају различити случајеви контрадикторне перформативне двосмислености руског опсценог табу-лексикона, који се обично назива „псовкама“. Посебна пажња посвећена је радикалном карневалском апсурду (Бахтин) и прагматичној поливалентности идиоматских исказа, о којима се расправља. Чланак се такође фокусира на различите углове полисемије. Рад прелиминарно оцртава контуре будуће теорије опсценог исказивања у вези са шизоаналитичким ризомом њеног језичког функционисања.

Кључне речи: теорија исказивања, амфиболије, полисемија, прагматика, говорно безумље, полифонија, руски опсцени идиоми, шизоанализа. 